NBER WORKING PAPER SERIES

\title{
FOREIGN DIRECT INVESTMENT AND KNOWLEDGE DIFFUSION IN POOR LOCATIONS
}

\author{
Girum Abebe \\ Margaret S. McMillan \\ Michel Serafinelli \\ Working Paper 24461 \\ http://www.nber.org/papers/w24461 \\ NATIONAL BUREAU OF ECONOMIC RESEARCH \\ 1050 Massachusetts Avenue \\ Cambridge, MA 02138 \\ March 2018, Revised February 2021
}

We thank Nathaniel Baum-Snow, Loren Brandt, Pamela Campa, David Card, Kunal Dasgupta, Eike J Eser, Zhexin Feng, Christian Fons-Rosen, Matthias Heinz, Enrico Moretti, Marco Gonzales Navarro, Peter Morrow, Jonas Hjort, Richard Hornbeck, Thierry Mayer, Anna Raute, Marco Sanfilippo, Seyhun Orcan Sakalli, William Strange, Petra Thiemann, Eric Verhoogen, Etienne Wasmer, Genet Zinabou and seminar participants at Essex, IMF, Universitat Autonoma de Barcelona, Oxford, NBER Summer Institute PRDP, NYUAD, CEPR - PEDL Research Workshop, IGC Growth Week, Trinity College Dublin, SAEe 2017, RCEF 2016, University of Toronto, York University, University of Bristol, CEMFI, Wilfrid Laurier University, EEA 2018, AFSE 2018, ISER, University of Cologne, Milano MILLS, the CReAM UCL Workshop in Labour Economics, the Firms, Markets, and Development workshop at the Ortygia Business School and the Foreign Investment and Structural Transformation in Africa workshop in Addis Ababa for suggestions, and Mia Ellis, Yiwei Jiang, Jed Silver, Inigo Verduzco for excellent research assistance. We also thank plants' employees who have generously given their time in interviews. We thank the International Food Policy Research Institute's program Policies, Institutions and Markets, PEDL, and the University of Toronto Connaught Fund for financial support. The views expressed herein are those of the authors and do not necessarily reflect the views of the National Bureau of Economic Research.

NBER working papers are circulated for discussion and comment purposes. They have not been peer-reviewed or been subject to the review by the NBER Board of Directors that accompanies official NBER publications.

(C) 2018 by Girum Abebe, Margaret S. McMillan, and Michel Serafinelli. All rights reserved. Short sections of text, not to exceed two paragraphs, may be quoted without explicit permission provided that full credit, including $(\odot$ notice, is given to the source. 
Foreign Direct Investment and Knowledge Diffusion in Poor Locations

Girum Abebe, Margaret S. McMillan, and Michel Serafinelli

NBER Working Paper No. 24461

March 2018, Revised February 2021

JEL No. D24,F21,R10

\begin{abstract}
We use a plant level survey to identify interactions between domestic plants and foreign direct investment (FDI) in Ethiopia's manufacturing sector. One third of Ethiopian plants are linked to FDI through labor sharing, supply chains and competition. Technology upgrading most commonly occurs as a result of competition in output markets and observation and imitation of FDI in the same line of business. Other benefits include enhanced managerial practices and knowledge about exporting. Spillovers from FDI are identified by comparing changes in total factor productivity (TFP) among domestic plants in districts where a large greenfield foreign plant produces and districts where FDI in the same industry and around the same time was licensed but not yet operational. Over the four years starting with the year of the FDI opening, the TFP of domestic plants is 11 percent higher in treated districts, employment in domestic plants increases and more domestic plants open.

Girum Abebe

World Bank

Addis Ababa

Ethiopia

girumpop@yahoo.com

Margaret S. McMillan

Tufts University

Department of Economics

114a Braker Hall

Medford, MA 02155

and International Food Policy Research Institute

and also NBER

margaret.mcmillan@tufts.edu

Michel Serafinelli

Department of Economics

University of Toronto

Max Gluskin House, 150 St. George Street, 270

Toronto, Ontario M5S 3G7, Canada

michel.serafinelli@utoronto.ca
\end{abstract}




\section{Introduction}

The gaps in productivity between developed and developing countries are large; the poorer the country, the larger the gap. Foreign direct investment (FDI) could be a powerful tool for reducing these productivity gaps. Standard means of raising productivity such as investments in education and health are obviously important but they are costly and typically take a long time to bear fruit. By contrast on-the-job training and other types of learning could be less costly and have more immediate payoffs (Romer, 1992). In fact, it is now common for developing countries to include attracting FDI as an integral part of their industrialization strategies (World Investment Report, 2018).

Despite their theoretical and practical importance, the existence and magnitude of knowledge spillovers from foreign to domestic firms are considered open questions. This is especially the case for very poor countries like Ethiopia where - arguably - FDI could have the largest relative impact. In addition, most of the evidence for spillovers has been restricted to foreign firms and their suppliers. Yet, in a country like Ethiopia where supply chains are underdeveloped, the benefits of exposure to FDI are more likely to come through other channels. For example, Ethiopian plants commonly report: (i) directly adopting production techniques through observation and imitation of foreign plants in the same line of business and; (ii) technology upgrading as a result of competition from FDI. In fact, we have very little systematic evidence on the mechanisms by which knowledge is transferred from foreign to domestic plants (Balsvik, 2011; Poole, 2013; Newman et al., 2015).

This paper has two objectives. First, we present evidence on the mechanisms by which knowledge is transferred from foreign to domestic plants. This evidence is the result of a technology-transfer survey designed by us in cooperation with Ethiopia's Central Statistical Agency (CSA) and administered as part of Ethiopia's annual census of manufacturing plants. Apart from horizontal and vertical linkages, the survey asks about learning by observation, labor sharing and the transfer of "soft" as opposed to technical knowledge. Second, we test for and quantify spillovers from FDI in the Ethiopian manufacturing sector by estimating how the productivity of incumbent plants changes when a large greenfield foreign plant opens in an Ethiopian district (Woreda). Focusing on spillovers at the local level has two advantages. First, it 
allows us to construct a plausible counterfactual. Second, the spillovers generated at the local level are likely to be of first-order importance and thus easier to identify.

Previous research typically classifies the interactions between foreign and domestic plants into horizontal or vertical. Horizontal spillovers occur between plants classified in the same industry while vertical spillovers occur between foreign plants and their suppliers or their customers. While these definitions are analytically useful, they may be too restrictive. For example, Poole (2013) finds evidence of knowledge sharing through labor movements from foreign to domestic plants irrespective of industry. Moreover, recent evidence indicates that managerial skills that are not a priori industry specific are a key determinant of plant productivity (Bloom and Van Reenen, 2010). And Bloom et al. (2018) find that knowledge spillovers from large manufacturing plants in the U.S. enhance the management practices of smaller manufacturing plants in a variety of industries. ${ }^{1}$

The key question throughout this literature is whether knowledge from foreign plants can be assimilated by domestic plants. When put in these terms, the similarity between research that investigates knowledge diffusion between foreign and domestic plants and research on agglomeration externalities becomes evident. For example, Rosenthal and Strange (2003) and Kantor and Whalley (2014) explain that geographic proximity plays a key role in the acquisition of skills and that one of the benefits of clustering is that it facilitates learning. And Greenstone, Hornbeck and Moretti (2010) quantify these agglomeration spillovers by comparing changes in total factor productivity (TFP) among plants in 'winning' counties that attracted a large manufacturing plant and 'losing' counties that were the new plant's runner-up choice.

Based on this literature, one may expect that the spillovers stemming from the presence of foreign plants would be obtained first by nearby domestic plants, and maybe slowly diffuse to other, more distant domestic plants. This is likely to be the case for instance if trained employees move from a foreign plant to a neighboring domestic plant or if the foreign plant uses a product, production process, managerial technique, organizational form, or export market formerly unknown to domestic plants.

The results from the 2013 technology transfer module confirm that domestic plants in close geographic proximity to foreign plants are three times more likely to report being linked to foreign

\footnotetext{
${ }^{1}$ Another example of spillovers that are not a-priori industry specific are corporate governance spillovers (Albuquerque et al., 2013).
} 
plants (Figure 1). The survey results also reveal that more than one quarter of Ethiopian plants report being linked to foreign plants through labor sharing, forward and backward linkages and competition in input and output markets. These domestic plants report learning from foreign plants through supply chain interactions, labor sharing, and observation and imitation. They also report that exposure to foreign plants enhances domestic plants: (i) production processes; (ii) managerial and organizational practices; and, (iii) knowledge about exporting.

The survey results provide suggestive evidence that the presence of FDI causes some domestic plants to be more productive. To formally test for and quantify the magnitude of these spillovers at the local level, we estimate augmented Cobb-Douglas production functions that allow the TFP of domestic plants to depend on the presence of a new foreign plant. We use plant-level data from Ethiopia's Annual Census of Manufactures.

Because the foreign plant's location decision is made to maximize profits, the chosen district may differ substantially from an average or randomly chosen district, both at the time of the opening and in future periods. District characteristics that affect the foreign and domestic plant's TFP and that are difficult to measure include local transportation infrastructure, current and future costs of inputs, quality of the labor force, presence of intermediate input providers, and any other local cost shifters.

To identify the causal relationship between the opening of a foreign plant and domestic plants' productivity, we compare changes in TFP among domestic plants in 'treatment' districts to changes in TFP in 'control' districts. Treatment districts are defined as districts in which a large greenfield foreign plant produced. Using restricted-access administrative data from the Ethiopian Investment Commission, we define a control district as a location in which a foreign plant in the same industry and around the same time, applied for a license, got approval but then did not produce during the period in which the foreign plant was operating in the treated district. As explained below, bureaucratic hurdles are the most cited explanations for why there exists a lag in investment translations. The pre-trends in the treatment and control districts look similar; this finding is consistent with our identifying assumption that plants in the control districts form a valid counterfactual for the plants in the treated districts.

Our baseline estimates show an increase in TFP for treated domestic plants following the start of production of a greenfield foreign plant. Over the four years starting with the year in which the foreign plant opens the average increase in the TFP of domestic plants is 11 percent. The results 
are robust to alternative specifications addressing the issue of the endogeneity of inputs and are not driven by attrition of domestic plants or government expenditures on capital and infrastructure construction. And the estimated FDI effect does not appear to reflect higher output prices. ${ }^{2}$ Moreover, we obtain qualitatively similar results using an alternative strategy exploiting the assignment of land for FDI by the Ethiopian Government, in combination with an event study research design. ${ }^{3}$

New domestic plants may choose to locate in the districts receiving FDI to gain access to these productivity advantages. Thus, an indirect test of knowledge spillovers is a test for plant entry in treated districts. We find that following the entry of the foreign plant in a district there is an increase in the number of domestic plant openings. These results are consistent with the estimated increases in TFP and indicate that foreign plants attract new economic activity in the manufacturing sector to treated districts. We also document an increase in employment at treated domestic plants.

Our survey results also indicate competition between FDI and domestic plants in both input and output markets. To test for competition in the labor market, we explore changes in wages in domestic plants exposed to FDI entry. We find little evidence of an impact of FDI entry on wages and attribute this to the relative abundance of unskilled labor in Ethiopia. Note though that we do not have worker characteristics or wages broken down by skill level which leaves open the possibility that wages for some skill groups did increase.

Tests for attrition and employment changes serve as indirect tests for the relative importance of competition between FDI and domestic plants in both input and output markets. Competition could lead to relatively more attrition of domestic plants in the treatment group. It could also lead to layoffs. We find no evidence for differential attrition by treatment status. And

\footnotetext{
${ }^{2}$ To explore this possibility, we adopt two approaches. First, we remove domestic plants in a supply link with the new entrant, plants for which output price effects might be largest. Second, we investigate whether the TFP increase is bigger for plants that sell more locally.

${ }^{3}$ We consider as valid events the openings of foreign plants reporting that their location was allocated by the authorities - information which is reported in our technology transfer survey. Our research design then compares the TFP of domestic plants within a district before and after the opening. The regions targeted by the government are non-random; in particular the government often targets regions with higher needs in terms of investment. However, the exact geographic location within a broader region is typically determined by the availability of land. Moreover, the timing is often out of the hands of the government since there is substantial uncertainty about the exact year in which the foreign plant will start production. We estimate our econometric model with and without the never treated localities; in the latter case identification comes from the differential timing of treatment onset among the treated localities.
} 
as previously noted, instead of layoffs, we find evidence of employment expansion by plants in treated districts.

Our work contributes to the literature on knowledge spillovers from foreign direct investment in two ways. First, we overcome the identification problem that plagues much of the literature on spillovers associated with FDI by homing in on the local effects of FDI. Focusing on the local effects enables us to construct a plausible counterfactual. Moreover, as mentioned above, the local effects are likely to be of first-order importance. While our work is unlikely to settle the debate regarding the magnitude of knowledge spillovers, the evidence presented in this paper strongly supports the existence of knowledge flows from foreign to domestic plants.

Second, we present evidence based on a national census of manufacturing plants on the mechanisms by which knowledge is assimilated from foreign plants by domestic plants. Like previous work, ${ }^{4}$ Ethiopian plants report productivity improvements as a result of selling to foreign plants. Similarly, ${ }^{5}$ Ethiopian plants report that hiring workers trained by foreign plants leads to productivity gains. However, and unlike previous work, we find that the two most important channels through which technology upgrading occurs are through the observation and imitation of plants in the same line of business and through direct competition in the product market. These results are important because they imply that in a very poor country where domestic firms are not yet sophisticated enough to sell directly to foreign firms, exposure to FDI still has the potential to impact technology upgrading.

Our work also contributes to the empirical literature that examines the productivity advantages of agglomeration, recently reviewed by Combes and Gobillon (2015). Although there is evidence, mostly from analysis using data for developed countries, that significant agglomeration effects exist, the jury is still out over the nature of the microeconomic mechanisms that can account for these advantages (Baum-Snow, 2013; Kline and Moretti, 2014; Severnini, 2014; Cabral, Wang and Xu, 2018; Helm, 2020).

While the issues analyzed in this paper are of general interest, the specific case of Ethiopia is also important. Ethiopia is Africa's fastest growing country and has been for well over a decade. The government of Ethiopia has made industrialization with the help of FDI a key pillar of its

\footnotetext{
${ }^{4}$ See for example: Javorcik (2004), Kugler (2006), Blalock and Gertler (2008), Javorcik and Spatareanu (2009), Javorcik and Spatareanu (2011), Newman et al. (2015), and Alfaro-Urena, Manelici and Vasquez (2019).

${ }^{5}$ See for example: Balsvik (2011), Poole (2013), and Fons-Rosen et al. (2018)
} 
growth strategy. Many on the continent of Africa view Ethiopia as an example to emulate. However, we have very little systematic evidence about how this strategy is playing out in the context of Ethiopia. Our results are generally supportive of an industrial policy that seek to attract foreign direct investment for the purposes of upgrading domestic plants' capabilities. ${ }^{6}$

Finally, our results underscore the importance of geographic proximity for realizing these gains. Special Economic Zones (SEZs) - a key albeit relatively recent element of Ethiopia's industrialization strategy - could limit interactions between foreign and domestic plants. This may happen if foreign plants locate in highly secure relatively remote locations or if foreign plants are given preferential access to SEZs because for example they export. This concern is not just relevant to African countries; SEZs are among the most popular instruments for attracting FDI and the number of SEZs has grown rapidly over the past ten years with many more planned (UNCTAD, 2019).

The remainder of this paper is organized as follows. Section 2 presents evidence from the technology transfer survey. Section 3 presents our conceptual framework, Section 4 presents the foreign plant location decision and research design, and Section 5 describes the data and presents summary statistics. In Section 6 we outline our econometric model, we present our estimates of the magnitude of total factor productivity spillovers from FDI and discuss the validity and robustness of our estimates. Section 7 presents evidence on domestic plant entry, employment and wages. Section 8 concludes.

\section{Evidence from the Technology Transfer Survey}

To obtain evidence on whether and how knowledge is transferred from foreign to domestic plants, we designed a technology transfer survey (available upon request). The survey was administered by Ethiopia's Central Statistical Agency in 2014 as part of their annual census of large and medium sized enterprises and covers the year 2013. The survey was administered to plant managers and was designed to elicit information about (i) formal links between foreign and domestic plants; (ii) the mechanisms by which knowledge is transferred from foreign to domestic plants, and; (iii) the benefits obtained by domestic plants from foreign plants. Out of the 1,708

\footnotetext{
${ }^{6}$ The next step in this line of research would be to calculate the potential costs - both direct and indirect - of attracting foreign direct investment including foregone tax revenues and the construction of Special Economic Zones (SEZs).
} 
plants surveyed, 81.4 percent $(1,390)$ were wholly domestically owned; the remaining plants were primarily wholly foreign owned.

The survey is organized into 6 sections. The first section asks for respondent information. The second section asks about ownership and plant location. Section 3, labeled horizontal linkages asks questions of plants that make and sell similar products as foreign plants. Section 4 is designed to determine the extent of customer and supplier — or vertical-linkages between foreign and domestic plants. Section 5 includes questions about technology and innovation and the final section includes questions about labor and training.

Results from the survey are reported below. We divide this descriptive evidence into four parts. First, we report on formal ties between foreign and domestic plants. Second, we report on the mechanisms by which knowledge is transferred from foreign to domestic plants. Third, we report the benefits obtained from foreign plants making a distinction between benefits obtained by plants in formal relationships with foreign plants and benefits obtained through observation and word of mouth. Finally, we assess the extent to which observable characteristics of plants predict the extent to which they are likely to benefit from FDI.

\subsection{How are foreign and domestic plants connected?}

Domestic plant managers were asked to respond to the following questions about links to foreign plants based in Ethiopia: (i) have you faced competition from foreign plants in output markets? (ii) have you ever faced competition from foreign plants in the labor market? (iii) have you ever hired labor previously employed by a foreign plant? (iv) do you purchase inputs from foreign plants? and; (v) do you sell inputs to foreign plants? We label these relationships, horizontally linked, labor competition linked, labor linked, supplier linked, and customer linked respectively.

Responses to these questions are presented in Table 1. More than a quarter of all domestic plants (28.9 percent) reported at least one connection to foreign plants. Competition in output markets was the most commonly reported linkage-15.5 percent of domestically owned plants reported facing competition from foreign plants in output markets. 5.8 percent of plants reported facing competition from foreign plants in the labor market, while 7 percent of plants reported hiring labor previously employed by foreign plants. 9 and 6.3 percent reported purchasing inputs from and selling inputs to foreign plants, respectively. 


\subsection{How is knowledge transferred from foreign to domestic plants?}

A second set of questions asks plants about the ways in which they learn from foreign plants based in Ethiopia. These questions include: (i) has the plant ever directly adopted production techniques/processes (by observing or copying) from FDI competitors within the same ISIC 4digit industry? (ii) has the plant ever upgraded production technologies due to competition from FDI? (iii) has the plant benefitted from employing workers who previously worked in foreign plants? (iv) has the plant obtained knowledge from foreign customers? (v) has the plant obtained knowledge from foreign suppliers? And finally (vi) has the plant ever licensed technology from foreign plants?

Table 2 shows that the most common mechanism is upgrading production technologies due to competition from foreign plants -15.4 percent of plants report this happening. 12.7 percent report that they directly adopted production techniques from observing or copying foreign plants in the same sector. 10.2 percent of plants report licensing technology from foreign plants. A further 6.3 percent report benefiting from hiring workers who previously worked in foreign plants ${ }^{7}$. Just 4.5 percent reported upgrading as a result of relations with foreign customer plants, while only 1.9 percent reported doing so as a result of relations with foreign supplier plants.

These results highlight the idea that knowledge transfers occur through somewhat indirect routes. A significant number of plants that reported experiencing knowledge transfers of some sort from foreign plants reported that it was through the observation and imitation and through upgrading because of competition from foreign plants. These mechanisms do not necessarily require formal relationships such as customer/supplier linkages but may still lead to sustained benefits. This highlights the potential for the presence of foreign plants to result in positive spillovers to domestic plants.

\subsection{Benefits of knowledge transfer}

We next report on the benefits domestic plants attain from their linkages with foreign plants. Plant managers who reported some type of knowledge transfer were then asked to report

\footnotetext{
${ }^{7}$ These findings are in line with previous evidence from developed countries. Serafinelli (2019) finds evidence of labor market-based knowledge spillovers in the Veneto region of Italy. In a similar vein, (Saxenian, 1994, p.37) maintains that the geographic proximity of high-tech plants in Silicon Valley is associated with a more efficient flow of new ideas.
} 
on the types of benefits obtained from the presence of foreign plants. The general form of these questions is: what is the nature of the knowledge that was transferred? Possible responses to this question were: (i) improvements in production processes and design; (ii) improvements in managerial practices and quality control systems; (iii) improvements in organizational structure and; (iv) knowledge about how to export.

Responses to these questions are presented in Figure 2. Benefits reported are as follows: 69.7 percent of plants reported improved production technologies; 9.09 percent reported increased knowledge of how to export, 8.33 percent improved managerial practices, and 7.58 percent improved organizational structure. ${ }^{8}$ These results make clear that improvements to production technologies are, by far, the most common sort of benefit attained through knowledge transfers.

\subsection{Which plants are more likely to be linked to FDI?}

In this section we use data from both the industrial survey and the technology transfer module to explore whether there are characteristics distinct to those plants that are linked to FDI. We consider whether the plant is located in the same woreda as a foreign plant, the plant size, and the industry. To estimate the relationship between these characteristics and whether a plant is linked to FDI, we construct a dummy variable Link that is equal to one if the plant reported any one of the five linkages in section 2.1, and zero otherwise. These five linkages are: i) hired employees who previously worked in a foreign plant, ii) faced competition from FDI in the labor market, iii) faced competition from FDI in output markets, iv) sells output to foreign plants, and v) buys inputs from foreign plants. The regression equation is:

$$
\operatorname{Link}_{p i d}=\alpha+\theta 1\left(F D I_{P R E S E N C E}\right)_{d}+\sigma S I Z E_{p i d}+\eta_{i}+\varepsilon_{p i d}
$$

where $p$ references plant, $i$ industry, $d$ district; the dummy $1\left(F D I_{P R E S E N C E}\right)$ is equal to one if plant $p$ is located in the same woreda as a foreign plant; we present results with and without allowing for differences across industries $\left(\eta_{i}\right)$, and with and without the introduction of the plant's size $\left(S I Z E_{p i d}\right)$ measured as a categorical variable based on the number of employees. The OLS

\footnotetext{
${ }^{8}$ There was a fifth possible response, 'other'. We exclude this category as we do not have information about what 'other' might refer to because the very small number of plants that reported "other" did not list specific benefits for which they had not been prompted.
} 
estimates, reported in Table 3, indicate that being located in the same woreda as a foreign plant is associated with an increase of between 9 and 20 percentage points in the probability of being linked to FDI. This compares to a mean likelihood of being linked of around 13 percent in the group of plants in Woreda without FDI presence. Plant size also has a positive and significant association with Link indicating that larger domestic plants are more likely to be linked to foreign plants. Finally, there is significant variation in the likelihood of links to FDI across industries.

\section{Conceptual Framework}

The results in Section 2 indicate that more than a quarter of domestic plants in Ethiopia report that they are impacted by the presence of FDI. Moreover, the results in Section 2.4 indicate that plants in close geographic proximity to foreign plants are significantly more likely to be impacted by FDI than domestic plants geographically further away. We incorporate these stylized facts into a simple model that guides our empirical work.

\subsection{Theoretical Model}

Our model adapts insights from Rosenthal and Strange (2004) and Greenstone, Hornbeck and Moretti (2010, GHM). Like GHM (2010) and for the sake of simplicity, we focus on the case of Hicks-neutral technological progress. Instead of focusing on the number of plants in a county, we allow linkages between domestic and foreign plants to depend upon the geographic distance between foreign and domestic plants. ${ }^{9}$

We assume that all domestic plants use a production technology that employs labor, capital, land and other material inputs to produce a nationally traded good whose price is normalized to one. Domestic plants choose the amount of inputs to maximize the following expression:

$$
\max _{L, K, T} f(A, L, K, T)-w L-r K-q T
$$

where $w, r$, and $q$ are input prices and $A$ is a productivity shifter. $A$ includes all factors that affect the productivity of labor, capital and land equally, such as knowledge spillovers from FDI.

We model $A$ as a function of the geographic proximity between domestic and foreign plants, denoted as $p$. Thus, we can write the expression for $A$ in the following way:

\footnotetext{
${ }^{9}$ We are not strictly testing for agglomeration economies; instead, we are using relevant insights from this literature to set up our model.
} 


$$
A=A(p)
$$

We define factor-neutral knowledge spillovers as the case in which an increase in the proximity of domestic to foreign plants increases the knowledge spillovers from foreign to domestic plants so that $\partial A / \partial p>0$.

We define $L^{*}(w, r, q)$ as the optimal level of labor inputs, given market wages, the cost of capital, and the cost of industrial land. Similarly, we define $K^{*}(w, r, q)$ and $T^{*}(w, r, q)$ as the optimal levels of capital and land respectively. In equilibrium, $L^{*}, K^{*}$, and $T^{*}$ are chosen so that the marginal product of each of the three factors is equal to its price. In Ethiopia, the markets for credit and land cannot be characterized as perfectly competitive. Instead, land and capital are typically allocated through a central mechanism with subsidies to both domestic and foreign plants in the manufacturing sector. ${ }^{10}$ Thus, in our optimization, we do not allow the prices of land or capital paid by domestic plants to be influenced by the proximity between foreign and domestic plants. Instead, we take the prices of land and capital as exogenous.

However, we allow for wages to depend on the proximity of domestic plants to foreign plants. The extent to which wages would rise as foreign plants enter local labor markets in Ethiopia is unclear. Job opportunities in Ethiopia's formal sector are limited and unemployment is high. At the same time, labor productivity in Ethiopia's traditional sectors is very low. Taken together, these facts suggest a relatively flat horizontal labor supply curve at a low level of wages. Indeed, cheap labor is one of the reasons foreign entrepreneurs are drawn to Ethiopia. On the other hand, the literature provides ample evidence from other, albeit more developed countries, that foreign plants pay a wage premium. Thus, domestic plants in close proximity to foreign plants may be forced to pay higher wages to keep or attract labor, especially in managerial or administrative positions.

Summarizing, we allow $w$ to vary as a function of $p$ writing this as $w(p)$ and we take $r$ and $q$ as fixed by the central government. Note that although the prices of land and capital are set centrally, plants still choose quantities to employ in the production process. Thus, we can write equilibrium profits in the following way:

\footnotetext{
${ }^{10}$ According to the urban land lease proclamation, along with religious institutions and embassies, investments in the manufacturing sector are entitled to easy and cheap access to land directly from the government (FDRE, 2011). Credit is also subsidized by the Development Bank of Ethiopia (DBE) through its generous 70 (loan):30 (equity) policy for priority sectors, which include manufacturing (AFDB, 2014).
} 


$$
\begin{aligned}
& \pi^{*}=f\left[A(p), L^{*}(w(p), r, q), K^{*}(w(p), r, q), T^{*}(w(p), r, q)\right] \\
& -w(p) L^{*}(w(p), r, q)-r K^{*}(w(p), r, q)-q T^{*}(w(p), r, q)
\end{aligned}
$$

Equation (3) makes it clear that domestic plants' profits, TFP, and wages depend on their proximity to foreign plants.

To understand the relationship between domestic plants' profits and changes in domestic plants' proximity to foreign plants, we totally differentiate equilibrium profits. This yields the following expression:

$$
\frac{d \pi^{*}}{d p}=\frac{\partial f}{\partial A} \frac{\partial A}{\partial p}+\frac{\partial w}{\partial p}\left\{\left[\left(\frac{\partial L^{*}}{\partial w}\right)\left(\frac{\partial f}{\partial L}-w\right)-L^{*}\right]+\left[\left(\frac{\partial K^{*}}{\partial w}\right)\left(\frac{\partial f}{\partial K}-r\right)\right]+\left[\left(\frac{\partial T^{*}}{\partial w}\right)\left(\frac{\partial f}{\partial T}-q\right)\right]\right\}
$$

If domestic plants are price takers, and factors are employed until their marginal value product equals their price, equation (5) simplifies to the following:

$$
\frac{d \pi^{*}}{d p}=\frac{\partial f}{\partial A} \frac{\partial A}{\partial p}-\frac{\partial w}{\partial p} L^{*}
$$

Equation (6) makes it clear that being closer to foreign plants has two opposing effects on domestic plants. If there are knowledge spillovers from foreign plants to domestic plants, the first term in equation (6) will be positive, raising the profits of domestic plants. The second term in equation (6) represents the negative effect that foreign plants could have on domestic plants if being close to foreign plants implies an increase in wages that domestic plants must pay to keep labor. Note that although we did not include material costs in our model, this result would generalize to the cost of other inputs. In other words, the demand by foreign plants for material inputs which are produced locally could raise the prices of these inputs.

\subsection{Empirical Predictions}

The simple framework above combined with insights from our technology transfer survey lead to a number of testable predictions that inform our empirical analysis. In particular, the opening of a foreign plant may:

1. Increase the TFP of domestic plants if there are positive spillovers from FDI; 
2. increase the profits of domestic plants in a location thereby temporarily increasing entry by domestic plants and/or hiring by domestic plants if there are positive spillovers from FDI;

3. increase wages if foreign and domestic plants compete for labor.

In addition, our framework emphasizes the results from Section 2 by making it clear that these effects are more likely to be experienced by domestic plants in close geographic proximity to foreign plants.

\section{$4 \quad$ Foreign Plant Location Decision and Research Design}

Our goal is to estimate the effect of FDI at the local level. Specifically, we estimate the impact of FDI on the total factor productivity (TFP) of domestic plants allowing the impact to depend on the presence of FDI in the district (Woreda). See Figure A.1 for a map which shows Woreda boundaries. Specifically, we would like to evaluate the changes in the TFP of domestic plants when a foreign plant is added to a district. The underlying idea — supported by the survey evidence - is that the impacts of FDI would be localized at least initially, with domestic plants in the same district more likely to be impacted by the presence of FDI.

Our primary identification challenge is that foreign companies do not select the location for their greenfield plants randomly. Like all companies, foreign companies aim to maximize profits. Thus, the location decision depends on local cost shifters (such as the quality of the labor force and transportation infrastructure), which are likely to be correlated with the TFP of domestic plants and are often difficult to quantify. Consequently, a simple contrast of the TFP of domestic plants in districts where a greenfield foreign plant opens with the TFP of domestic plants in districts where a foreign plant does not open is likely to produce biased estimates of FDI spillovers.

We address this empirical challenge by comparing domestic plants in districts where an FDI plant became operational (treatment districts/plants) to districts in which a foreign plant in the same industry and around the same time applied for a license, got approval, but then did not produce during the period in which the foreign plant was operating in the treated district (control districts/plants). For each treatment district, at least one control district is found; the algorithm used to find control districts is described in Section A.I.

Our identifying assumption is that the trend in domestic plants' TFP would have been 
identical in the absence of FDI in treatment and control districts, after conditioning on plant fixed effects, industry by year fixed effects, and other control variables. Essentially, we are arguing that the patterns of "conversion" from the investment stage to the operational phase are not determined by unobservable district-level characteristics that would also impact the productivity of domestic plants but rather by institutional and regulatory inefficiencies at the federal and regional levels. This argument is supported by accounts from foreign investors who report that the main obstacles to going forward with investments are: (i) trade regulations and customs clearance; and, (ii) inconsistent and frequently changing tax laws (Hailu, 2017). As Geiger and Moller (2015, p. 44) write, "Even though a One Stop Shop service is operational, its effectiveness record is mixed. Bureaucratic hurdles continue to affect project implementation." Additionally, local governments do not appear to have the autonomy to significantly impact the investment climate in their districts. For example, Ayele and Fessha (2012, p.103) conclude that "the constitutional recognition of local government has fallen short of clearly articulating the powers and functions of local government. Unlike most other federal systems, the powers of local government are not even defined in the regional constitutions, or by way of ordinary regional legislation." Furthermore, local governments have fiscal incentives to conform to the will of regional and federal governments as they are largely financially reliant on regional and federal government grants.

As we show in Section 6.1, before the foreign plant started production, plants in treatment and control districts were similar along several key dimensions, and there were not significant differences in TFP trends. This evidence supports the validity of our identifying assumption. Even if this assumption fails to hold, our strategy is arguably more reliable than employing regression adjustment to compare the TFP of domestic plants in districts with new entrants to the other (nearly 300) districts in our data featuring manufacturing activity, or employing a matching approach based on observables (see GHM, p. 552).

Finally, the federal and local governments in some cases set up worker training funds, construct new roads, and make other infrastructure investments around the time of entry of a foreign plant. It is possible that these investments benefit domestic plants in addition to the foreign plant. To examine this possibility, we control for government total capital expenditures and government fixed assets and construction expenditures. 


\section{Data Sources and Summary Statistics}

\subsection{Data}

To estimate the Impact of FDI on domestic plant productivity we use two data sources: plant-level manufacturing census data for the years 1997-2013 collected by the Central Statistical Agency (CSA) and restricted-access administrative data from the Ethiopian Investment Commission. We describe these data below.

Manufacturing Census The source of manufacturing plant data is the annual Large and Medium Scale Manufacturing (LMSM) Establishment Census of the CSA. It consists of enterprises engaged in "the mechanical, physical, or chemical transformation of materials, substances, or components into new products and the assembling of component and parts of manufactured products" (CSA, 2015). ${ }^{11}$ The available information includes employment, material and non-material inputs, capital stock, sales, geographic location, date of plant establishment, and asset ownership. It is worth pointing out that with these records it is possible to construct a genuine panel of manufacturing plants.

We faced three main challenges trying to link plant identifiers (IDs) across years: 1) verifying that, pre-2011/12, unique IDs were consistent across years, that is, that they identify the same plant across the different rounds; 2) doing the same for the 2011/12 and 2012/13 rounds independently of the pre-2011/12 data, and; 3) linking plants between these two separate datasets.

To check that plant IDs were unique and consistent across years we relied on information available on phone numbers, location of the plant (e.g. region, zone, woreda, etc.), the Ethiopian Electric Power Corporation (EEPCO) number of the plant, and the P.O. box number. As a further consistency check, we used the business directory that CSA compiled as a 'framework' for the census for 2008/09. ${ }^{12}$ This list is compiled by CSA every year with data from different ministries and government agencies as a reference to identify which plants exist and should be interviewed

\footnotetext{
${ }^{11}$ In principle, any formal manufacturing plant in the country that employs at least 10 people and uses electricity in its production process forms part of the target population. In practice, out of the 20,711 plant-year observations, 5,445 feature a number of employees smaller than 10. These are observations for plants that at some point reach 10 employees (and therefore enter the business directory that CSA compiled as a "framework" for the census) but then have a lower number of employees at the date in which they are re-surveyed. In the TFP estimation, the results are similar when we remove these plant-year observations.

${ }^{12}$ Similar lists for other rounds of the LMSM are not available. According to the Director of the Business Statistics Directorate, due to changes in management and issues with the storing of data, the lists for other years have been lost.
} 
for the survey. The list includes the name and plant number that CSA assigns to each plant during that round, as well as phone number and locational information (e.g. region, zone, woreda, town, etc.).

While there is typically no electronic record of the plant's name in the database, it is possible to compile this information directly from the paper questionnaires. CSA staff went through all available paper questionnaires that CSA had in storage, collected plant names from each paper questionnaire, and linked plants across available years using this information. ${ }^{13}$ This effort was crucial in creating the panel identifiers for two reasons. First, it provided a link between the pre- and post-2011/12 rounds. Second, it provided us with additional information to validate unique plant IDs for rounds between 2008/09 and 2010/11.

During the final stage we evaluated the different matches obtained from all methods described above and determined which matches were valid. This was done using Stata to the extent possible but, in most cases, a visual inspection of the validity of each match was necessary to ascertain the match provided by Stata. If matches did not seem valid then, a case-by-case match was done manually. If no valid match was found, the observation was left unmatched and a new unique ID was created for the plant. Figure A.2 shows the count of plants and the total employment by year in the matched CSA sample. Table A.1 reports descriptive statistics.

Administrative Data To implement our research design, we use restricted-access administrative data from the Ethiopian Investment Commission. This dataset contains the list of licensed FDI manufacturing investment projects during our sample period. It includes information on the date of permit, the industry, the location, and the status of the investment (whether or not it is operational).

\subsection{Summary Statistics}

Table 4 presents summary statistics for the 12 usable events in our dataset. Since our goal is to identify a substantial shock to a district's economy, we require a large relative increase in local employment. In order to qualify as a usable event, we impose the requirement that the foreign plant's labor force is at least 100 employees or constitutes at least 1 percent of total employment in local manufacturing in $\tau=0$ or $\tau=1$. We also require that the location is not

\footnotetext{
${ }^{13} \mathrm{CSA}$ staff were only able to retrieve paper questionnaires for the last five rounds of the LMSM — it is CSA's policy to store paper questionnaires for no more than five years.
} 
assigned by the government. We have a total of 27 districts, 15 of which are controls. FDI plants tend to be in food and beverages (5), chemicals and chemical products (3), and other nonmetallic mineral products (3).

Table 5 displays the means of plant-level variables across districts in $\tau=-1$ and the percentage change between $\tau=-4$ and $\tau=-1$. These means are shown for treatment and control districts in Columns 1 and 2 respectively. Column 3 reports the p-value from a test of equality between Columns 1 and 2. Column 4 reports the p-values obtained using the procedure recommended by Cameron, Gelbach and Miller (2008). This exercise offers a chance to evaluate the soundness of the empirical strategy, as measured by preexisting observable plant characteristics. To the extent that these observable features are balanced among treated and control districts, this lends support to the research design. The table shows that there are not significant differences in plant age, the number of employees and its growth, capital and its growth, capital per worker and its growth, plant-level average yearly wage and its growth. ${ }^{14}$ Overall, we conclude that the covariates are balanced between plants in treatment and control districts. We estimate differences in pre-trends in Section 6.1 and also find no significant difference in pre-trends in TFP between treatment and control plants.

\section{Effects of FDI on Domestic Plant Productivity}

\subsection{Econometric Model}

The regression equation that forms the basis of our empirical analysis on the sample of domestic plants is:

$$
\begin{gathered}
\ln \left(Y_{\text {pidrt }}\right)=\beta_{L} \ln \left(L_{\text {pidrt }}\right)+\beta_{K} \ln \left(K_{\text {pidrt }}\right)+\beta_{M} \ln \left(M_{\text {pidrt }}\right)+\delta 1\left({\text { FDI_PRODUCTION })_{d}+}+\right. \\
\varkappa 1(\tau \geq 0)_{d t}+\varphi\left[1(\text { FDI_PRODUCTION })_{d} \cdot 1(\tau \geq 0)_{d t}\right]+\alpha_{p}+\mu_{i t}+\text { Trend }_{r t}+\varepsilon_{\text {pidrt }}
\end{gathered}
$$

where $p$ references plant, $i$ industry, $d$ district, $r$ region, and $t$ year; $Y_{\text {pidrt }}$ is the value of total plant production, and we allow the total number of employees $L_{\text {pidrt }}$, total capital inputs

\footnotetext{
${ }^{14}$ Conclusions are similar when plants are weighted by the inverse of their number per district.
} 
$K_{\text {pidrt }}$, and material inputs $M_{\text {pidrt }}$ to have separate impacts on output ${ }^{15}$; we also allow for permanent differences across plants $\alpha_{p}$, industry-specific time-varying shocks $\mu_{i t}$, and a stochastic error term $\varepsilon_{\text {pidrt }}$. The dummy $1($ FDI_PRODUCTION) is equal to one if plant $p$ is located in a treatment district; $\tau$ denotes year, but it is normalized so that the year when the foreign plant started production is $\tau=0$; the variable Trend $_{r t}$ is a region-specific trend. A concern for the validity of our interpretation of the estimates arises from the observation that the dependent variable in the econometric model is the value of output. Therefore, the estimated spillover effect may reflect higher output prices rather than higher productivity-we explore this possibility in Section 6.3. We report standard errors clustered at the district level. Given that the number of districts is equal to 27 , we also report the p-values obtained using wild bootstrap ( $\mathrm{Wu}, 1986)$ with null imposed, as recommended by Cameron, Gelbach and Miller (2008) - we use the boottest Stata routine developed by Roodman (2018).

\subsection{Baseline Results}

Figure 3 reports the yearly difference between estimated mean TFP in treatment and control districts, with confidence intervals. The estimated coefficients are obtained from a version of equation 7. Specifically, the natural log of output is regressed on the natural log of inputs, year by two-digit industry fixed effects, plant fixed effects, and the event time indicators. The sample is restricted to include only plant by year observations within the period of interest (where $\tau$ ranges from -4 through 3 ). The graph shows that in the years before the new plants starts production, treatment and control districts do not have significantly different trends in productivity. This evidence brings support to the validity of the research design. After the start of the FDI production, there appears to be a change in the difference in TFP between the treatment and control districts.

The displayed coefficients on the event time dummies in Figure A.3 indicate yearly mean TFP in treatment districts and control districts, relative to the year before the foreign plant opened. Interestingly, the patterns are similar to the ones shown in GHM for the period between $\tau=-4$ and $\tau=3$ (see their Figure 1, Panel A at p. 565).

\footnotetext{
${ }^{15}$ Capital stock is given by the full amount of the paid up capital of the firm including investments in asset and land in a given period. Material cost reflects expenses incurred to procure intermediate products including raw materials and inputs.
} 
Table 6 shows the estimated mean shift parameter, i.e. the estimate of the parameter $\varphi$ in equation 7. Column 1 reports baseline estimates, which imply an increase in TFP of approximately 11 percent. Estimates are similar when domestic plants are required to be in the data for at least 3 years prior to the event, which addresses concerns related to the endogenous opening of new plants and compositional bias (Column 2).

A significant conceptual concern is the possibility of 'transmission bias', which arises from plants' reaction to unobservable productivity shocks when making input choices. Because unobservable shocks 'transmit' to input choices, inputs should be treated as endogenous. Unlike the typical estimation of plant-level production functions, our goal is to obtain a consistent estimate of the diff-in-diff coefficient corresponding to the FDI entry, so transmission bias is important only to the extent that it causes biased estimates of this coefficient (GHM p. 583). In order to explore the significance of transmission bias in our setting we control for flexible functions of capital, materials, and labor (Levinsohn and Petrin, 2003; Ackerberg, Caves and Frazer, 2015). The estimates (shown in Columns 3-4) also indicate an increase in TFP of domestic plants.

\subsection{Validity and Robustness}

The main empirical result so far is that after the opening of a large foreign plant, the TFP of domestic plants is significantly higher in treated districts. We now investigate the sensitivity of this finding to various specifications and explore several possible alternative explanations for the estimated effects.

Attrition of Sample Plants A gap in attrition in the sample of domestic plants in treatment and control districts could contribute to the measured gap in TFP among survivors after the FDI opening. The evidence suggests that this is unlikely to explain our finding of positive FDI effects in treatment districts. We find that similar numbers of treatment and control plants remained in the sample at its end: 52 percent in treatment districts and 54 percent in control districts (i.e., the number of plants at $\tau=3$ as a fraction of the number of plants at $\tau=0$ ).

Government expenditures The federal and local governments in some cases set up worker training funds, construct new roads, and make other infrastructure investments around the time of entry of a foreign plant. It is possible that these investments benefit domestic plants in addition to the foreign plant. To examine this possibility, we control for government total capital expenditures 
and government fixed assets and construction expenditures. ${ }^{16}$ Columns 1 and 2 of Table 7 show that the main conclusions are unchanged.

Changes in the Price of Plant Output As mentioned above, another concern for the validity of our interpretation of the estimates arises from the observation that the dependent variable in the econometric model is the value of output. The theoretically correct dependent variable in a productivity study is the quantity of output, but, due to data limitations, this study (and most of the empirical literature on productivity in a large sample of plants) uses price multiplied by quantity. Therefore, the estimated spillover effect may reflect higher output prices rather than higher productivity. To explore this possibility, we adopt two approaches. First, we remove domestic plants in a supply link with the new entrant, plants for which output price effects might be largest. Since we observe the presence of a supply link only in the last year, we focus on the sample that survives until the end of our sample period. These estimates (shown in Column 3 of Table 7) also indicate an increase in TFP of domestic plants.

Second, we follow GHM and investigate whether the TFP increase is bigger for plants that sell more locally. Specifically, in our survey we have asked domestic plants the distance to the most important customer. This allows us to estimate a version of equation (7) that interacts 1(FDI_PRODUCTION), $1(\tau \geq 0)$, and [1(FDI_PRODUCTION $) \cdot 1(\tau \geq 0)]$ with this distance. We do not find that the TFP increase is bigger for plants that sell more locally. Specifically, the coefficient of the interaction of $\left[1\left(F D I_{-} P R O D U C T I O N\right) \cdot 1(\tau \geq 0)\right]$ with this distance is equal to -0.0002 and not significant (s.e. 0.0004).

Changes in the intensity of capital usage If the capital stock in treated districts was used below capacity, then domestic plants may react to the FDI opening by growing the intensity of their capital usage and therefore increase production (GHM p. 585). To explore this possibility, we control for the ratio of the dollar value of energy usage (which is increasing in the use of the capital stock) to the capital stock. The estimates, displayed in Column 4 of Table 7, are similar to the main ones.

Other functional forms We also experiment with different functional forms to test our results. In Column 5 of Table 6, inputs are modeled with a translog function form. In Column 6, we allow the effect of each production input to differ at the 2-digit industry level to account for

\footnotetext{
${ }^{16} \mathrm{We}$ thank the Ministry of Finance and Economy for providing the data.
} 
possible differences in technology or quality of inputs across industries. Finally, in Column 7, we allow the effect of inputs to differ in treated/control districts and before/after the FDI opening. In all three cases, the estimates support our findings from the baseline specification.

Making use of government designation of locations As an alternative empirical strategy, we exploit the government designation of locations for greenfield foreign plants, in combination with an event study research design.

In order to implement this second empirical strategy, we asked plant managers what the most important reason for choosing the location for the production facility was. We consider as valid events for our identification strategy the openings of foreign plants reporting "Did not choose the location, was allocated by the authorities". ${ }^{17}$ We now provide some institutional background to the investment land allocation process. Both federal and regional offices are in many cases involved in the process. In an email interview, the General Director of Policy and Program Studies at the Ministry of Industry explained how the ministry, after receiving a request from a potential investor typically contacts a Regional office responsible for investment land administration (Ahmed Nuru, email interview, December 23, 2015). The Regional office then provides information on the land availability.

The regions targeted by the federal government are non-random. In particular, in order to foster equitable regional growth, the government often targets regions (outside Addis and its surrounding areas) with higher needs in terms of investment (FDRE, 2011). ${ }^{18}$ However, during our period of analysis, the exact district within a broader region is typically determined by the timing of availability of land. As pointed out to us by the General Director of Policy and Program Studies in the same email interview, in no case is the process coercive. An investor can always refuse to carry on with the investment or choose some other location instead. ${ }^{19}$ However, the fact that plant managers report that location was not chosen but allocated provides support to our strategy of using government designation to obtain quasi-experimental variation in the treatment. Moreover,

\footnotetext{
${ }^{17}$ The other possible answers are "Cheap labor", "Good infrastructure", "Located close to raw materials and input suppliers", "Located close to customers", "Located close to producers of similar products", "Expected that many more producers would be located in this site", and "Others (specify)".

${ }^{18} \mathrm{We}$ include region trends in all our specifications.

${ }^{19}$ If the investor is interested in the location, negotiations take place on the price and terms of lease. Note that in Ethiopia land is publicly owned and both local and foreign plants can enter into lease-hold or rental arrangements to acquire land for investment.
} 
the timing is often out of the hands of the government since there is substantial uncertainty in which year the foreign plant will start production.

In the words of a manager at a foreign plant:

It was not up to us to choose the location for our company. The [Federal] government gave us the location that we have now. That is usually the case. [...] After asking for the land, we just waited for the responses of the [Federal] government. After a long time they gave us the location. [...] The time we waited was two years. [..] This is because of the procedures that the offices of the government follow which often take time. [...] I didn't think that it would take such a long period of time to get land for investment (middle-manager at FDI (recorded interview, Jan 10, 2017, manager at FDI plant with 112 employees in Sululta and Adama, Oromiya Regional State).

In general, the local TFP impact of the entry of the foreign plants may be identified provided that there are no district-specific pre-trends in the outcomes of interest, a condition that appears to be satisfied in the data. We evaluate the local impact of FDI using an "event-study" research design, as in Kline (2011). This design allows us to test for the presence of districtspecific pre-trends in the outcome of interest and to recover any dynamics of the opening effect. Our main approach is to compare the "treated" districts both to districts that have not yet been treated and districts that will never be treated during our sample period. We then re-estimate our econometric model without the never treated localities, so that identification comes from the differential timing of treatment onset among the treated. The econometric model, descriptive statistics, and estimates are described in Section A.II. Overall the results we obtain are qualitatively similar to the baseline ones.

\section{Beyond Productivity: Entry, Employment and Wages}

Do the foreign plants attract new economic activity? Baseline estimates showed positive TFP changes for local domestic plants following the opening of the new foreign plant. Thus, new manufacturing domestic plants may choose to locate in the districts receiving FDI to gain access to these productivity advantages. Motivated by this observation, we estimate:

$$
\begin{aligned}
& \log (B)_{d r t}=\delta I\left(F D I_{-} P R O D U C T I O N\right)_{d}+\varkappa I(\tau \geq 0)_{d t}+\varphi\left[I\left(F F D I_{-} \text {PRODUCTION }\right)_{d} .\right. \\
& \left.I(\tau \geq 0)_{d t}\right]+\alpha_{d}+\psi_{t}+\operatorname{Trend}_{r t}+\varepsilon_{d r t}
\end{aligned}
$$


where $B$ stand for births, i.e. is the count of new domestic plants, and $\psi_{t}$ is a year effect. The estimates in Column 1 of Table 8 imply a 47 percent increase in the number of domestic plant openings. To put the size of the estimated impact of the FDI opening in perspective, a 47 percent increase corresponds to a 0.7 -standard-deviation increase in the distribution of plant births. ${ }^{20}$ The FDI openings we consider are a key occurrence for these districts, and the implied change in the relative standing of districts is arguably sizable but not improbable (GHM, p. 589). The estimated change in births is consistent with the estimated increases in TFP since it appears that the foreign plants attracted new economic activity in the manufacturing sector to the receiving districts.

Employment In the remainder of Table 8 we study the changes in employment and wages in treated districts. The employment regression equation is:

$$
\begin{aligned}
\ln \left(L_{\text {pidrt }}\right) & =\delta I\left(F D I_{\text {PRODUCTION }}\right)_{d}+\varkappa I(\tau \geq 0)_{d t}+\varphi^{L}\left[I\left(F D I_{\text {PRODUCTION }}\right)_{d} \cdot I(\tau \geq 0)_{d t}\right]+ \\
\alpha_{p} & +\mu_{i t}+\text { Trend }_{r t}+\varepsilon_{\text {pidrt }}
\end{aligned}
$$

The estimates (shown in Column 2) imply a 24 percent increase in the total number of employees. This is equivalent to the average plant in the treatment districts adding around 20 employees to its payroll. The diff-in-diff coefficient is significant at the 5 percent level when clustering at the district level and at 10 percent when using the Cameron, Gelbach and Miller (2008) procedure.

Wages We also estimate equation (9) with wages as the dependent variable. This regression should be interpreted cautiously because we do not have individual-level wage data and we are forced to use (log) plant level average wage (constructed as total wage bill divided by the number of employees). Setting this concern aside, the estimated diff-in-diff coefficient (shown in Column 3) is positive, but small and not precisely estimated. Results are similar when controlling for the number of employees (Column 4).

\section{Concluding Remarks}

\footnotetext{
${ }^{20} \mathrm{We}$ obtain these quantities using the cross-sectional data from the LMSM Census for 2005, the midpoint of our sample period.
} 
This paper makes two main contributions. First, we provide evidence on the ways in which knowledge is transferred from foreign to domestic plants and on the types of knowledge that is transferred. Domestic plants report that they adopt technology from foreign plants through: (i) learning by observation; (ii) hiring workers who previously worked at foreign plants; (iii) direct contact via customer and supplier relationships; (iv) licensing technology from foreign plants; and, (v) competitive pressures. This learning is more common when domestic plants engage with foreign plants through labor or customer and supplier linkages. Knowledge about production processes is the most common type of benefit associated with FDI, but domestic plants also learn from foreign plants about managerial and organizational practices and logistical aspects of the supply chain, including exporting. This evidence underscores the usefulness of an empirical strategy that moves beyond the confines of industrial classifications.

Second, by comparing changes in TFP among domestic plants in 'treated' districts that attracted a large greenfield foreign plant and 'control' districts where greenfield FDI in the same industry was licensed but not yet operational, estimates of the magnitude of knowledge spillovers at the local level are identified. Over the four years starting with the year of the foreign plant opening, the TFP of domestic plants is 11 percent higher in treated districts. These estimates are comparable to estimates obtained using an alternative identification strategy that exploits the assignment of land to foreign investors by the Ethiopian government. We also find evidence that employment in these domestic plants increases, and foreign plants attract new economic activity to recipient districts.

The overall evidence lends strong support to the idea that FDI generates positive spillovers. Moreover, domestic plants located in close geographic proximity to foreign plants appear most likely to benefits from FDI. The results also provide some support for the Ethiopian government's industrial policy although more research is needed to quantify the cost of the incentives provided to foreign plants and to compare these costs with the benefits of knowledge spillovers. 


\section{References}

Ackerberg, D. A., Caves, K., Frazer, G., 2015. Identification properties of recent production function estimators. Econometrica, forthcoming.

AFDB, November 2014. East african manufacturing sector: Promoting technology productivity and linkages. Ethiopia country report, African Development Bank.

Albuquerque, R., Brandao-Marques, M. L., Ferreira, M. A., Matos, P., 2013. International corporate governance spillovers: Evidence from cross-border mergers and acquisitions. No. 13-234. International Monetary Fund.

Alfaro-Urena, A., Manelici, I., Vasquez, J. P., 2019. The Effects of Joining Multinational Supply Chains: New Evidence from Firm-to-Firm Linkages. Available at SSRN 3376129.

Ayele, Z. A., Fessha, Y. T., 2012. The constitutional status of local government in federal systems: The case of Ethiopia. Africa Today 58 (4), 89-109.

Balsvik, R., 2011. Is labor mobility a channel for spillovers from multinationals? evidence from Norwegian manufacturing. Review of Economics and Statistics 93 (1), 285-297.

Baum-Snow, N., 2013. Urban transport expansions, employment decentralization, and the spatial scope of agglomeration economies.

Bloom, N., Brynjolfsson, E., Foster, L., Jarmin, R., Patnaik, M., Saporta-Eksten, I., Van Reenen, J., 2018. What drives differences in management practices? American Economic Review. 26

Bloom, N., Van Reenen, J., 2010. New approaches to surveying organizations. The American Economic Review 100 (2), 105-109.

Cabral, L., Wang, Z., \& Xu, D. Y. (2018). Competitors, complementors, parents and places: Explaining regional agglomeration in the US auto industry. Review of Economic Dynamics, 30, 1-29. 
Cameron, A. C., Gelbach, J. B., Miller, D. L., 2008. Bootstrap-based improvements for inference with clustered errors. The Review of Economics and Statistics 90 (3), 414-427.

Combes, P., Duranton, G., Gobillon, L., Puga, D., Roux, S., 2012. The productivity advantages of large cities: Distinguishing agglomeration from firm selection. Econometrica.

Combes, P.-P., Gobillon, L., 2015. The empirics of agglomeration economies. In: Handbook of regional and urban economics. Vol. 5. Elsevier, pp. 247-348.

CSA, August 2015. Report on large and medium scale manufacturing and electricity industries survey. Statistical bulletin 580, Central Statistical Agency.

FDRE, 2011. Urban land lease holding proclamation no. 721/2011 18th year, no.4. Tech. rep., Federal Democratic Republic of Ethiopia, Addis Ababa, Ethiopia.

Fons-Rosen, C., Kalemli-Ozcan, S., Sorensen, B. E., Villegas-Sanchez, C., Volosovych, V., 2018. Foreign investment and domestic productivity: Identifying knowledge spillovers and competition effects. Tech. rep., National Bureau of Economic Research.

Geiger, M. T., Moller, L. C., July 2015. Fourth ethiopia economic update: overcoming constraints in the manufacturing sector. Working paper 97916, World Bank.

Blalock, G., \& Gertler, P. J. (2008). Welfare gains from foreign direct investment through technology transfer to local suppliers. Journal of international Economics, 74(2), 402-421.

Greenstone, M., Hornbeck, R., Moretti, E., 2010. Identifying agglomeration spillovers: Evidence from winners and losers of large plants openings. Journal of Political Economy 118, 536598.

Hailu, T., 2017. Foreign Direct Investment (FDI) Outlook in Ethiopia: An Evidence from Oromia Region Selected Special Zones. International Journal of African and Asian Studies Vol. $35,31-39$.

Helm, I., 2020. National industry trade shocks, local labor markets, and agglomeration spillovers. The Review of Economic Studies. 
Javorcik, B., 2004. Does foreign direct investment increase the productivity of domestic firms? in search of spillovers through backward linkages. The American Economic Review 94 (3), $605-627$.

Javorcik, B. S., Spatareanu, M., 2011. Does it matter where you come from? vertical spillovers from foreign direct investment and the origin of investors. Journal of Development Economics 96 (1), 126-138.

Javorcik, B. S., \& Spatareanu, M. (2009). Tough love: do Czech suppliers learn from their relationships with multinationals?. Scandinavian Journal of Economics, 111(4), 811-833.

Kantor, S. and Whalley, A., 2014. Knowledge spillovers from research universities: evidence from endowment value shocks. Review of Economics and Statistics, 96(1), pp.171-188.

Kline, P., 2011. The impact of juvenile curfew laws on arrests of youth and adults. American Law and Economics Review, ahr011.

Kline, P. and Moretti, E., 2014. Local economic development, agglomeration economies, and the big push: 100 years of evidence from the Tennessee Valley Authority. The Quarterly Journal of Economics, 129(1), pp.275-331.

Kugler, M., 2006. Spillovers from foreign direct investment: within or between industries? Journal of Development Economics 80 (2), 444-477.

Levinsohn, J., Petrin, A., 2003. Estimating production functions using inputs to control for unobservables. Review of Economic Studies 70 (2), 317-42.

Newman, C., Rand, J., Talbot, T., Tarp, F., 2015. Technology transfers, foreign investment and productivity spillovers. European Economic Review 76, 168-187. 28

Poole, J. P., 2013. Knowledge transfers from multinational to domestic firms: evidence from worker mobility. Review of Economics and Statistics 95 (2), 393-406.

Romer, P. M., 1992. Two strategies for economic development: using ideas and producing ideas. The World Bank Economic Review 6 (suppl 1), 63-91. 
Roodman, D., 2018. Boottest: Stata module to provide fast execution of the wild bootstrap with null imposed.

Rosenthal, S., Strange, W., 2003. Geography, industrial organization, and agglomeration. Review of Economics and Statistics 85 (2), 377-393.

Rosenthal, S., Strange, W., 2004. Evidence on the nature and sources of agglomeration economies. Handbook of Regional and Urban Economics 4, 2119-2171.

Saxenian, A., 1994. Regional Advantage: Culture and Competition in Silicon Valley and Route 128. Harvard University Press.

Serafinelli, M., 2019. 'Good' firms, worker flows and local productivity. Journal of Labor Economics 37 (3), 747-792.

Severnini, E., 2014. The power of hydroelectric dams: Agglomeration spillovers. IZA Discussion Paper No. 8082

United Nations Conference on Trade and Development (UNCTAD), 2018. World Investment Report: Investment and New Industrial Policies.

United Nations Conference on Trade and Development (UNCTAD), 2019. World Investment Report 2019: Special economic zones. New York and Geneva: United Nations.

Wu, C.-F. J., 1986. Jackknife, bootstrap and other resampling methods in regression analysis. the Annals of Statistics, 1261-1295. 
Figure 1: Domestic Plants' Linkages by Proximity to FDI

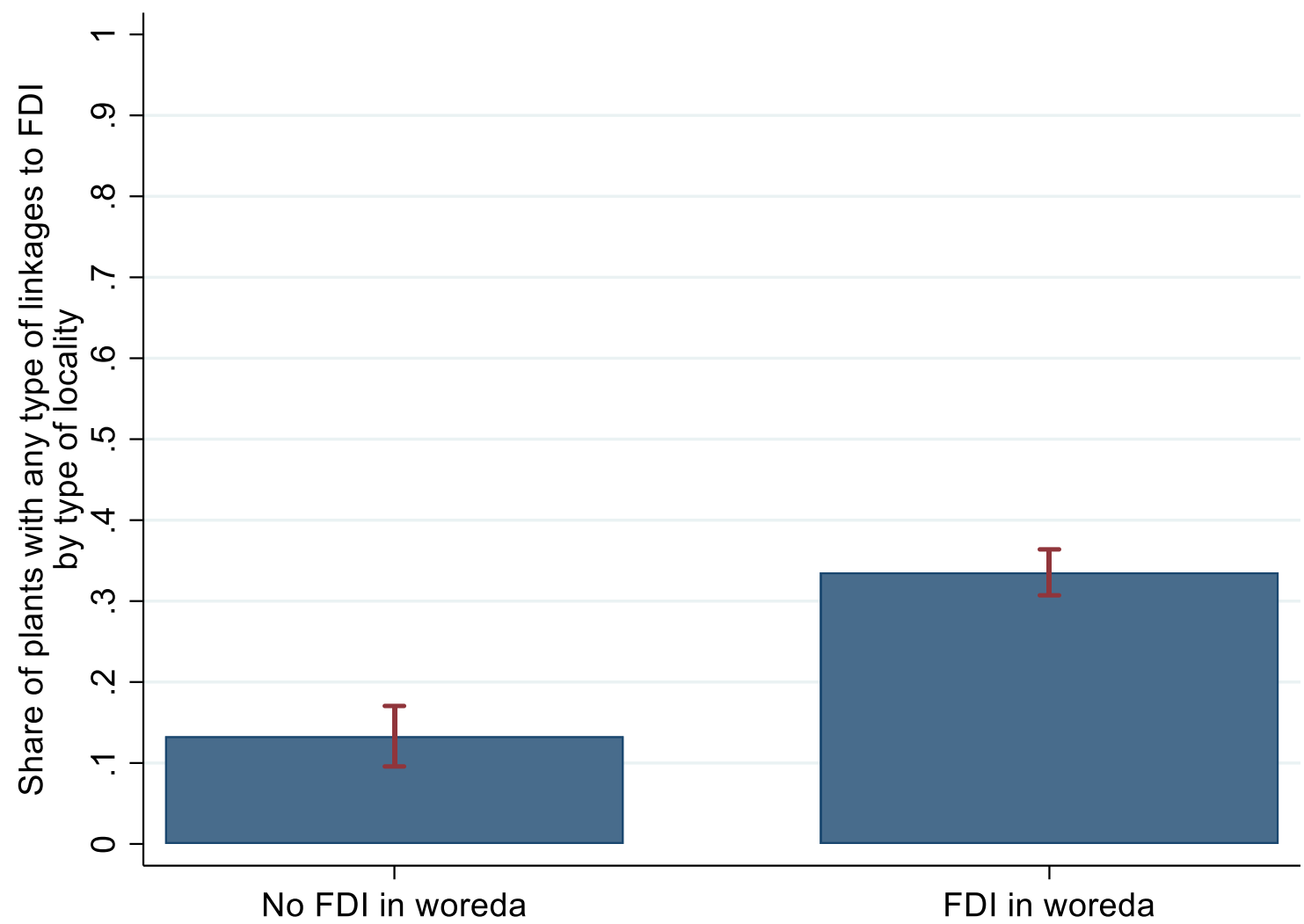

Note: The figure shows the share of domestic manufacturing plants that reported at least one of the following linkages to FDI-i) hired employees who previously worked in FDI plant, ii) faced competition from FDI in the labor market, iii) faced competition from FDI in output market, iv) sells output to FDI plants, and v) buys inputs from FDI plant - for localities (Woredas) with manufacturing FDI presence and localities without manufacturing FDI presence.

Source: Own calculations using Ethiopia Large and Medium Scale Manufacturing (LMSM) Establishment Census, 2013 (Technology Transfer Module) 
Figure 2: Benefits of Knowledge Transfer

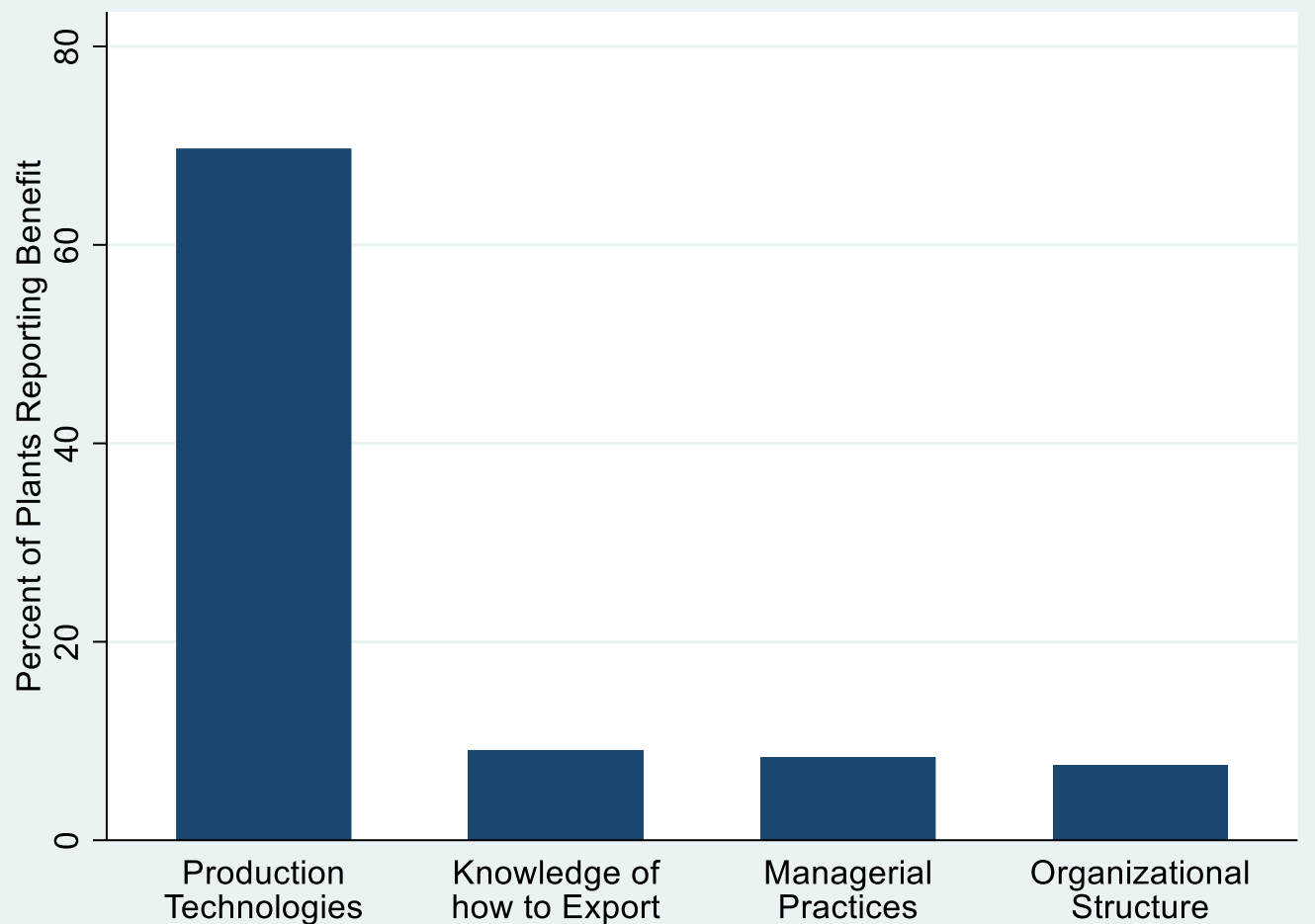

Note: Source: Ethiopia Large and Medium Scale Manufacturing (LMSM) Establishment Census, 2013 (Technology Transfer Module) 
Figure 3: Difference in Domestic Plants' Productivity in Treated vs. Control Districts, Relative to the Year of Start of FDI Production.

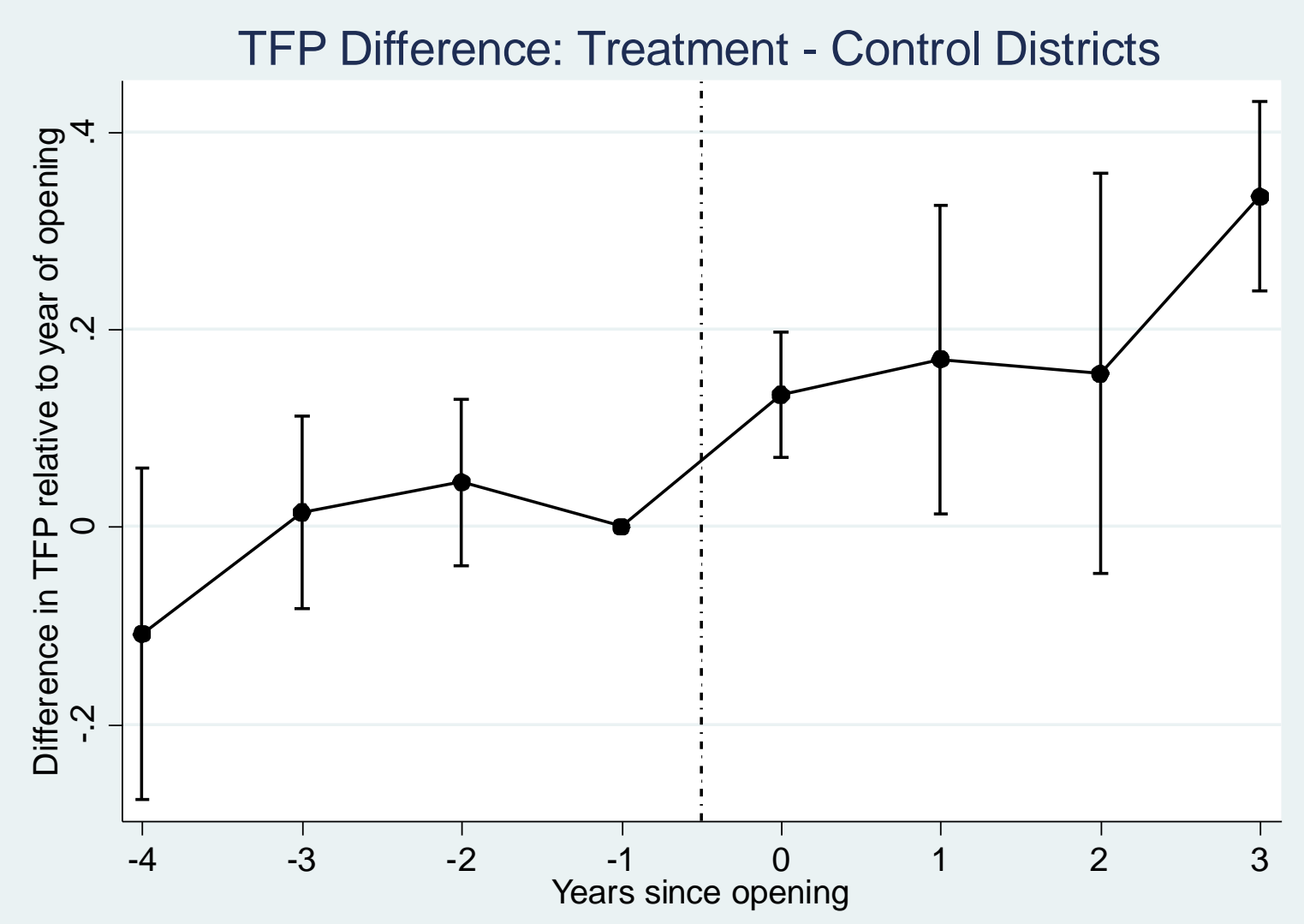

Note: The figure plots point estimates for leading and lagging indicators for the large foreign plant opening. The omitted category is one period prior to the large foreign plant opening. Vertical bars correspond to 95 percent confidence intervals with district-clustered standard errors. 
(i) Faced competition from foreign plants in output markets

(ii) Faced competition from foreign plants in labor markets

(iii) Hired labor previously employed by foreign plants

80

6.98

(iv) Purchases inputs from foreign plants

97

8.92

(v) Sells inputs to foreign plants

124

6.26

(vi) At least one of the above

87

28.85

Note: Source: Ethiopia Large and Medium Scale Manufacturing (LMSM) Establishment Census, 2013 (Technology Transfer Module) 
(i) Upgraded production technologies due to competition from foreign plants in the same sector

15.40

(ii) Directly adopted production techniques/processing by observing/copying from foreign plants in the same sector

(iii) Licenses technology from foreign plants

(iv) Benefitted from employing workers who previously worked in foreign plants

(v) Customer relations required upgrading, led to tech transfers that normally came from foreign customers

(vi) Supplier relations required upgrading, led to tech transfers that normally came from foreign suppliers

(vii) At least one of the above
12.66

10.22

6.33

4.46

1.87

30.00

Note: Source: Ethiopia Large and Medium Scale Manufacturing (LMSM) Establishment Census, 2013 (Technology Transfer Module) 
Table 3: Linkages to FDI, Locality, Size, and Sector

\begin{tabular}{|c|c|c|c|c|}
\hline VARIABLES & $\begin{array}{c}(1) \\
\text { Any Linkage } \\
\end{array}$ & $\begin{array}{c}(2) \\
\text { Any Linkage } \\
\end{array}$ & $\begin{array}{c}(3) \\
\text { Any Linkage }\end{array}$ & $\begin{array}{c}(4) \\
\text { Any Linkage } \\
\end{array}$ \\
\hline FDI plant in same Woreda ( $=1$ if yes, 0 otherwise) & $\begin{array}{l}0.203 * * * \\
(0.0239)\end{array}$ & $\begin{array}{l}0.139 * * * \\
(0.0239)\end{array}$ & $\begin{array}{l}0.124 * * * \\
(0.0244)\end{array}$ & $\begin{array}{l}0.0930^{* * *} \\
(0.0242)\end{array}$ \\
\hline Plant size - 20-49 employees & & $\begin{array}{c}0.165^{* * *} \\
(0.0301)\end{array}$ & & $\begin{array}{c}0.154 * * * \\
(0.0307)\end{array}$ \\
\hline Plant size - 50-99 employees & & $\begin{array}{l}0.198 * * * \\
(0.0432)\end{array}$ & & $\begin{array}{c}0.129 * * * \\
(0.0437)\end{array}$ \\
\hline Plant size - 100-499 employees & & $\begin{array}{l}0.331^{* * *} \\
(0.0408)\end{array}$ & & $\begin{array}{l}0.258 * * * \\
(0.0433)\end{array}$ \\
\hline Plant size - 500+ employees & & $\begin{array}{c}0.493 * * * \\
(0.0895)\end{array}$ & & $\begin{array}{l}0.414 * * * \\
(0.0866)\end{array}$ \\
\hline Constant & $\begin{array}{l}0.134 * * * \\
(0.0190)\end{array}$ & $\begin{array}{c}0.0716^{* * *} \\
(0.0186)\end{array}$ & $\begin{array}{c}0.0717 * * * \\
(0.0256)\end{array}$ & $\begin{array}{l}0.00151 \\
(0.0272)\end{array}$ \\
\hline $\begin{array}{l}\text { Industry dummies } \\
\text { F-test industry dummies, p-values }\end{array}$ & NO & NO & $\begin{array}{l}\text { YES } \\
0.0000\end{array}$ & $\begin{array}{c}\text { YES } \\
0.0000\end{array}$ \\
\hline $\begin{array}{l}\text { Observations } \\
\text { R-squared }\end{array}$ & $\begin{array}{l}1,386 \\
0.036\end{array}$ & $\begin{array}{l}1,386 \\
0.114\end{array}$ & $\begin{array}{l}1,386 \\
0.140\end{array}$ & $\begin{array}{l}1,386 \\
0.181\end{array}$ \\
\hline
\end{tabular}

Note: Any linkage indicates that a plant reported at least one of the following linkages: i) hired employees who previously worked in FDI plant, ii) faced competition from FDI in the labor market, iii) faced competition from FDI in output market, iv) sells output to FDI plants, and v) buys inputs from FDI plants. The mean likelihood of being linked is 13.3 percent in the group of plants in woredas without FDI presence. The reference employment size is 10-19 employees and the reference subsector is food processing. For the regressions with industry dummies (Columns 3-4), we test for the joint significance for the industry dummies; the p-values for these tests are displayed in the table. Robust SEs in parentheses. $* * * \mathrm{p}<0.01, * * \mathrm{p}<0.05, * \mathrm{p}<0.1$ 
Number of control districts per treatment district:

1 district

2 districts

Reported year of foreign plant opening:

2004-2007

2008-2010

Foreign plant industries:

Food \& beverages

Chemicals and chemical products

Non-metallic mineral products

Motor vehicles

Foreign plant characteristics:

Number of employees

Share of local labor market (\%)

(18.48)

Note: This table displays descriptive information on the usable openings and districts used in the first research design. The algorithm used to find control districts is described in Section A.I. The values for 'Number of employees' and 'Share of local labor market' are the average between $\tau=0$ and $\tau=1$. Standard deviations are shown in parentheses. 
Table 5: Plant Characteristics by Treatment Status, Prior to the start of FDI Production

(1)

Treatment

Districts
(2)

(3)

(4)

p-value (1)-(2)

(Cameron,

Gelbach and Miller)

Plant Age in $\tau=-1$

Employees in $\tau=-1$

Perc. Change between $\tau=-4$ and $\tau=-1$

Capital per Worker in $\tau=-1$

Perc. Change between $\tau=-4$ and $\tau=-1$

Capital in $\tau=-1$

Perc. Change between $\tau=-4$ and $\tau=-1$

Plant-level Average Yearly Wage in $\tau=-1$

Perc. Change between $\tau=-4$ and $\tau=-1$
15.0

84.7

25.3

75.0

21.1

$5,032.1$

44.1

6.5

30.3 p-value (1)-(2)

(Clustered)

Note: P-values in column 3 are calculated from standard errors clustered at the district level. P-values in column 4 are obtained using the bootstrap procedure developed by Cameron, Gelbach and Miller (2008). All monetary amounts are in 1000s of 2013 Birr. 1000 Birr are roughly equivalent to 34 USD using the 2018 exchange rate. 
Table 6: Changes in Domestic plants' productivity, following the start of FDI production

(1)

(2)

(3)

(4)

Materials-Capital

At least 3 years

Materials-Capital Interactions

and Materials-Labor Interactions

\begin{tabular}{|c|c|c|c|c|}
\hline $\log K$ & $\begin{array}{c}0.053 * * * \\
(0.017)\end{array}$ & $\begin{array}{c}0.045^{* * *} \\
(0.016)\end{array}$ & $\ldots$ & $\ldots$ \\
\hline $\log M$ & $\begin{array}{c}0.523 * * * \\
(0.054)\end{array}$ & $\begin{array}{c}0.506^{* * *} \\
(0.054)\end{array}$ & $\ldots$ & $\ldots$ \\
\hline $\log L$ & $\begin{array}{c}0.265^{* * *} * \\
(0.058)\end{array}$ & $\begin{array}{c}0.284 * * * \\
(0.057)\end{array}$ & $\begin{array}{c}0.228 * * * \\
(0.058)\end{array}$ & $\ldots$ \\
\hline Mean Shift & $\begin{array}{c}0.108 \\
(0.048)^{* *} \\
{[0.050]^{*}}\end{array}$ & $\begin{array}{c}0.136 \\
(0.046)^{* *} \\
{[0.022]^{* *}}\end{array}$ & $\begin{array}{c}0.106 \\
(0.046)^{* *} \\
{[0.044]^{* *}}\end{array}$ & $\begin{array}{c}0.098 \\
(0.045)^{* *} \\
{[0.026]^{* *}}\end{array}$ \\
\hline Observations & 10889 & 9331 & 10889 & 10889 \\
\hline Adjusted R-squared & 0.905 & 0.906 & 0.908 & 0.91 \\
\hline
\end{tabular}

Note: The table reports results from estimating eq. (7). Plant FE and region trends are always included.

Standard errors clustered at district level in parentheses. ${ }^{* * *} \mathrm{p}<0.01, * * \mathrm{p}<0.05, * \mathrm{p}<0.1$. For the mean shift, we report in brackets the p-value obtained using the bootstrap procedure the procedure developed by Cameron, Gelbach and Miller (2008). In Column 2 domestic plants in treated districts are required to be in the data for at least 3 years prior to the event. Column 3 adds to Column 1 a fourth-degree polynomial function of $\log$ capital and $\log$ materials and the interaction of both functions (see Levinsohn and Petrin 2003). Column 4 adds interactions between log materials and log labor to the controls in Column 3 (see Ackerberg, Caves and Frazer (2015)). 
Table 7: Changes in Domestic plants' productivity, following a foreign plant opening, Robustness to Different Specifications

\begin{tabular}{|c|c|c|c|c|c|c|c|}
\hline & $\begin{array}{l}\text { (1) } \\
\text { Control for } \\
\text { Gov't Capital } \\
\text { Expend. }\end{array}$ & $\begin{array}{c}\text { (2) } \\
\text { Control for } \\
\text { Gov't Fixed } \\
\text { Assets Expend. }\end{array}$ & $\begin{array}{l}\text { (3) } \\
\text { Drop plants with } \\
\text { Supply Link }\end{array}$ & $\begin{array}{c}\text { (4) } \\
\text { Control for } \\
\text { Intensity of } \\
\text { Capital Usage } \\
\end{array}$ & $\begin{array}{c}\text { (5) } \\
\text { Translog } \\
\text { Functional form }\end{array}$ & $\begin{array}{c}(6) \\
\text { Input - Industry } \\
\text { Interactions }\end{array}$ & $\begin{array}{l}(7) \\
\text { Input - Treated } \\
\text { and Input - Post } \\
\text { interactions }\end{array}$ \\
\hline Mean Shift & $\begin{array}{c}0.123 * * \\
(0.056)\end{array}$ & $\begin{array}{c}0.129 * * \\
(0.062)\end{array}$ & $\begin{array}{c}0.277 * * \\
(0.131)\end{array}$ & $\begin{array}{c}0.105^{* *} \\
(0.048)\end{array}$ & $\begin{array}{c}0.102 * * \\
(0.047)\end{array}$ & $\begin{array}{c}0.090 * * \\
(0.041)\end{array}$ & $\begin{array}{l}0.087 * \\
(0.046)\end{array}$ \\
\hline Observations & 7,803 & 7,803 & 2,419 & 10,889 & 10,889 & 10,889 & 10,889 \\
\hline Adjusted R-squared & 0.887 & 0.887 & 0.895 & 0.908 & 0.909 & 0.910 & 0.907 \\
\hline
\end{tabular}

Note: The dependent variable is $\log$ (Output). The table reports results from fitting several versions of eq. (7). In Columns 1 and 2 we control for government total capital expenditures and government fixed assets and construction expenditures, respectively. In Column 3 we remove domestic plants in a supply link with the new entrant. In Column 4 we control for the ratio of the dollar value of energy usage (which is increasing in the use of the capital stock) to the capital stock. Column 5 uses a translog function form for inputs, Column 6 allows the effect of each input to differ by 2digit industry, and Column 7 allows the effect of inputs to differ in treated/control districts and before/after FDI production. Standard errors clustered at district level in parentheses. $* * * p<0.01, * * p<0.05,{ }^{*} \mathrm{p}<0.1 . \log (\mathrm{L}), \log (\mathrm{K}), \log (\mathrm{M}), \operatorname{Industry} \mathrm{X}$ year dummies, plant FE and region trends always included. 
Table 8: Plant Entry, Employment, Wages

\begin{tabular}{lcccc}
\hline & $(1)$ & $(2)$ & $(3)$ & $(4)$ \\
& Log births & LogL & LogW & $\begin{array}{c}\text { Log W } \\
\text { (controlling for L) }\end{array}$ \\
\hline Mean Shift & & & & \\
& 0.471 & 0.235 & 0.001 & 0.024 \\
& $(0.241)^{*}$ & $(0.108)^{* *}$ & $(0.060)$ & $(0.062)$ \\
& {$[0.044]^{* *}$} & {$[0.065]^{*}$} & {$[0.859]$} & {$[0.690]$} \\
Observations & & & & 11398 \\
Adjusted R-squared & 156 & 11413 & 11398 & 0.648 \\
\hline
\end{tabular}

Note: Column 1 reports results from estimating eq. (8). The dependent variable is (log) count of new domestic plants. Column 2 reports results from estimating eq. (9). Dependent variable is $(\log )$ number of employees. In Column 3 we use (log) average plant-level wage as dependent variable; the rest of the regression equation is identical to eq. (9). In Column 4 we use (log) average plant-level wage as dependent variable and control for (log) number of employees. Standard errors clustered at district level in parentheses. ${ }^{* *} \mathrm{p}<0.01,{ }^{* *} \mathrm{p}<0.05, * \mathrm{p}<0.1$. We report in brackets the $\mathrm{p}$-value obtained using the bootstrap procedure developed by Cameron, Gelbach and Miller. (2008). 


\section{Appendix - For Online Publication}

\section{A.I Algorithm Used to Find Control Districts}

Our analysis required us to find at least one control district for each treatment one. We implemented an algorithm based on information on industry and time of approval of an FDI project. Let $\tau^{l i c}$ denote year but be normalized so that the year when the FDI project got approved (in a treatment district) is $\tau^{l i c}=0$. Our algorithm consisted of the following steps.

1. For each treatment district (characterized by a given year of approval of the project and a given industry) look for a control in the same year and with a foreign plant in same 4-digit industry (i.e. a district where an FDI plant in the same 4-digit industry and in the same year got approval but then did not open the plant during the period in which the foreign plant was operating in the treatment district)

2. If you cannot find one, look for a control in the same year in same 3-digit industry

3. If you cannot find one, look for a control in the same year in same 2-digit industry

4. If you cannot find one, look for a control district where the project was approved between $\tau^{l i c}=-1$ and $\tau^{l i c}=1$ (in the same 4-digit industry)

5. If you cannot find one, look for a control district where the project was approved between $\tau^{l i c}=-1$ and $\tau^{l i c}=1$ (in the same 3 -digit industry)

6. And so on for $\tau^{l i c} \in[-2,2]$ and $\tau^{l i c} \in[-3,3]$, until $\tau^{l i c} \in[-3,3]$ and same 2-digit industry

7. For the foreign plants which start operation but have a missing year of licence, assume the year of the licence $\tau^{l}=\tau-3 .^{21}$

8. Repeat steps 1-6 using the second list of treatment districts obtained in step 7

9. If multiple control districts are identified, keep them

10. If in a given year there are two treatment districts and one usable control district, pick randomly one treated district and discard the other

\footnotetext{
${ }^{21}$ Three years is the mean lag between licence and entry in the sample of FDI plants (a) whose labor force is at least 100 employees or constitutes at least 1 percent of total employment in local manufacturing in $\tau=0$ or $\tau=1$; and (b) whose location is not assigned by the government. See Figure A.4.
} 
11. If in a given year there are three treatment districts and two usable control districts, pick randomly two treated districts and discard the third. Assign randomly the two control districts to the two treatment districts

\section{A.II Making use of government designation of locations: econometric model,} descriptives and results

The regression equation that forms the basis of our empirical analysis is:

$$
\begin{aligned}
& \quad \ln \left(Y_{\text {pidrt }}\right)=\beta_{L} \ln \left(L_{\text {pidrt }}\right)+\beta_{K} \ln \left(K_{\text {pidrt }}\right)+\beta_{M} \ln \left(M_{\text {pidrt }}\right)+\sum_{\tau} \beta_{\tau} D_{\text {drt }}^{\tau}+\alpha_{p}+\mu_{i t}+ \\
& \text { Trend }_{r t}+\varepsilon_{\text {pidrt }}
\end{aligned}
$$

where $D_{d r t}^{\tau}$ are a sequence of "event-time" dummies indicating that the foreign plant opened (in district $d$ ) $\tau$ periods ago (where $\tau$ may be negative). Formally:

$$
\mid D_{d r t}^{\tau} \equiv I[t-e=\tau]
$$

where $I[$.$] is an indicator function for the expression in brackets being true, and e$ is the year of the plant entry. Therefore the $B_{\tau}$ coefficients characterize the time path of TFP relative to the date of the foreign plant opening for treated districts. The results are obtained by estimating Equation (10) by OLS, including a series of event-time dummies along with dummies for the plant and region-specific trends. We report results with and without including industry-year fixed effects. We normalize the first lead ( -1 in event time) to zero, so that all post-event coefficients can be interpreted as treatment effects. The event time indicator "-4" is set to 1 for periods up to and including 3 periods prior to the event and 0 otherwise. The event time indicator " +3 " is set to 1 for all periods 3 periods after the event and 0 otherwise $^{22}$. In order to qualify as a usable FDI manufacturing opening, we impose the following criteria. First, the location has to be assigned by the government. In our data 36 percent of FDI manufacturing openings report the location to be assigned by the government. Second, the FDI plant's labor force is at least 100 employees or

\footnotetext{
22 This constraint aids to diminish some of the collinearity between the year and event-time dummies. These endpoint coefficients give different weight to districts experiencing the entry of the foreign plant early or late in the sample period, since the sample of treated districts is unbalanced in event time. Therefore, in discussing the effect of the opening, we concentrate on the event-time coefficients falling within $\tau=0$ and $\tau=2$ that are identified off of a nearly balanced panel of districts.
} 
constitutes at least 1 percent of total employment in local manufacturing in $\tau=0$ or $\tau=1 .{ }^{23}$ Third, the opening is not preceded or followed by the entry of FDI whose location was chosen by the plants' owners (i.e. non "allocated by the authorities") and employing at least either 100 employees or 1 percent of the local manufacturing labor force. ${ }^{24}$ Table A.2 displays descriptive information on the 17 usable openings. We have a total of 223 control districts of which 206 are never treated. ${ }^{25}$ Openings tend to be in non-metallic mineral products (8), food and beverages (4), and wood, furniture and paper (3).

Figure A.5 plots the estimated $\beta_{\tau}$ coefficients from estimating Equation (10) and has two important features. First, there is no pretreatment trend in the coefficients. Second, there is a shift in TFP of local domestic plants after the entry of a government-assigned foreign plant. While the general pattern in Figure A.5 is quite clear, the individual $\beta_{\tau}$ coefficients are not estimated very precisely. We therefore offer more formal tests of the null hypothesis that the FDI plant entry has no impact on local plants' TFP. To increase statistical power, in Table A.3 we follow the approach in Kline (2011) and test hypotheses about the average of the $\beta_{\tau}$ coefficients over the period between $\tau=0$ and $\tau=2$. Column 1 reports baseline estimates: the estimated average increase over the three years starting with the year of the opening is 16 percent. In Column 2 of Table A.3 and Figure A.6 we drop the never treated localities, and therefore identification comes from the differential timing of treatment onset among the treated localities. In Column 3 of Table A.3 we require domestic plants in treated districts to be in the data for at least 3 years prior to the event. In Columns 4-5 we address the issue of transmission bias. These estimates also indicate an increase in TFP of domestic plants.

\footnotetext{
${ }^{23}$ In our data 39 percent of these large FDI manufacturing openings report the location to be assigned by the government.

${ }^{24}$ Specifically, we exclude districts that receive such openings in $\tau=(-3,3)$.

${ }^{25} \mathrm{We}$ exclude never-treated districts receiving the opening of a large foreign plant whose location was not "allocated by the authorities."
} 


\section{A.III Additional Figures and Tables}

Figure A.1: Administrative Map of Ethiopia

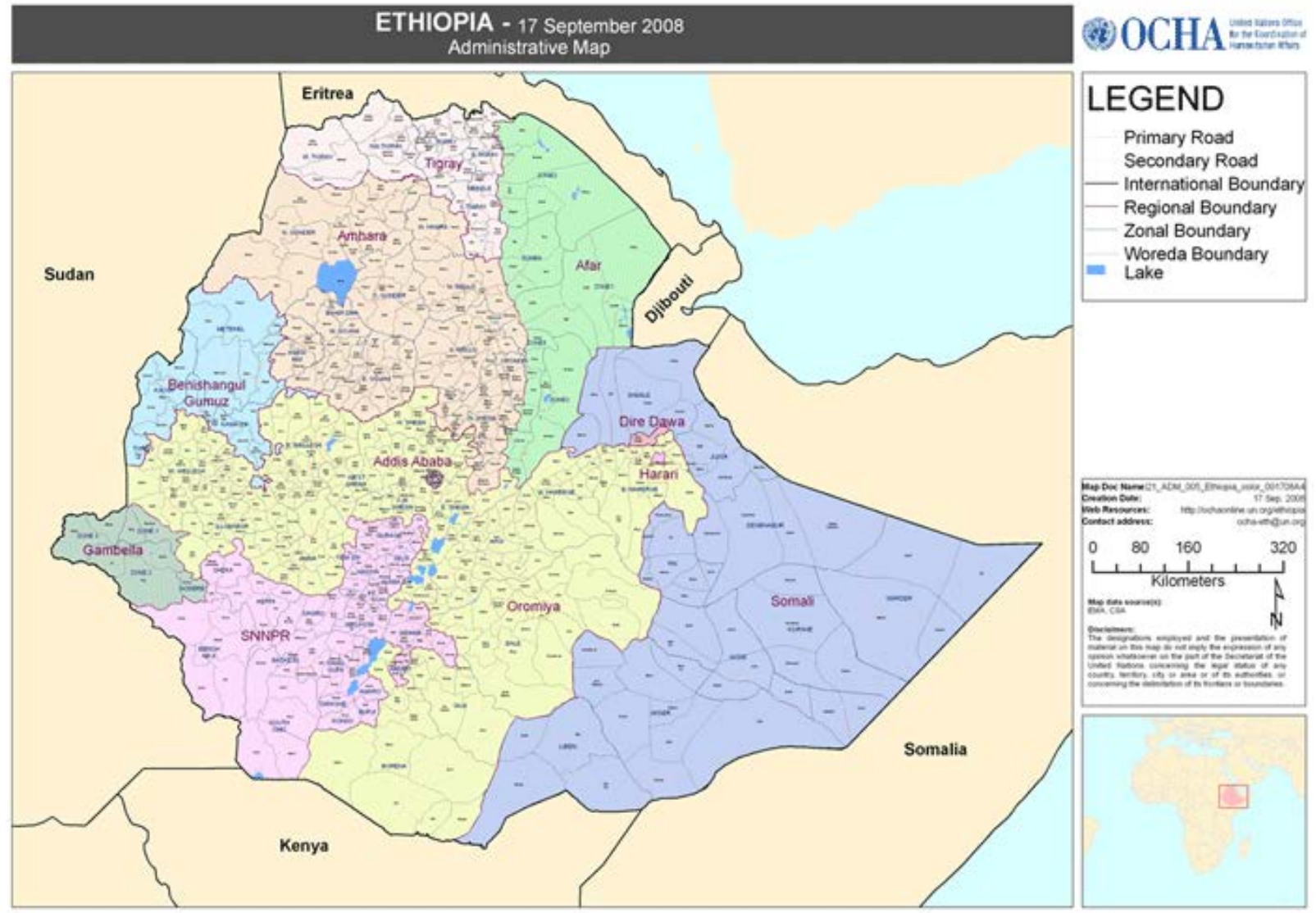

Source: UN Office for the Coordination of Humanitarian Affairs 
Figure A.2 CSA Matched Sample
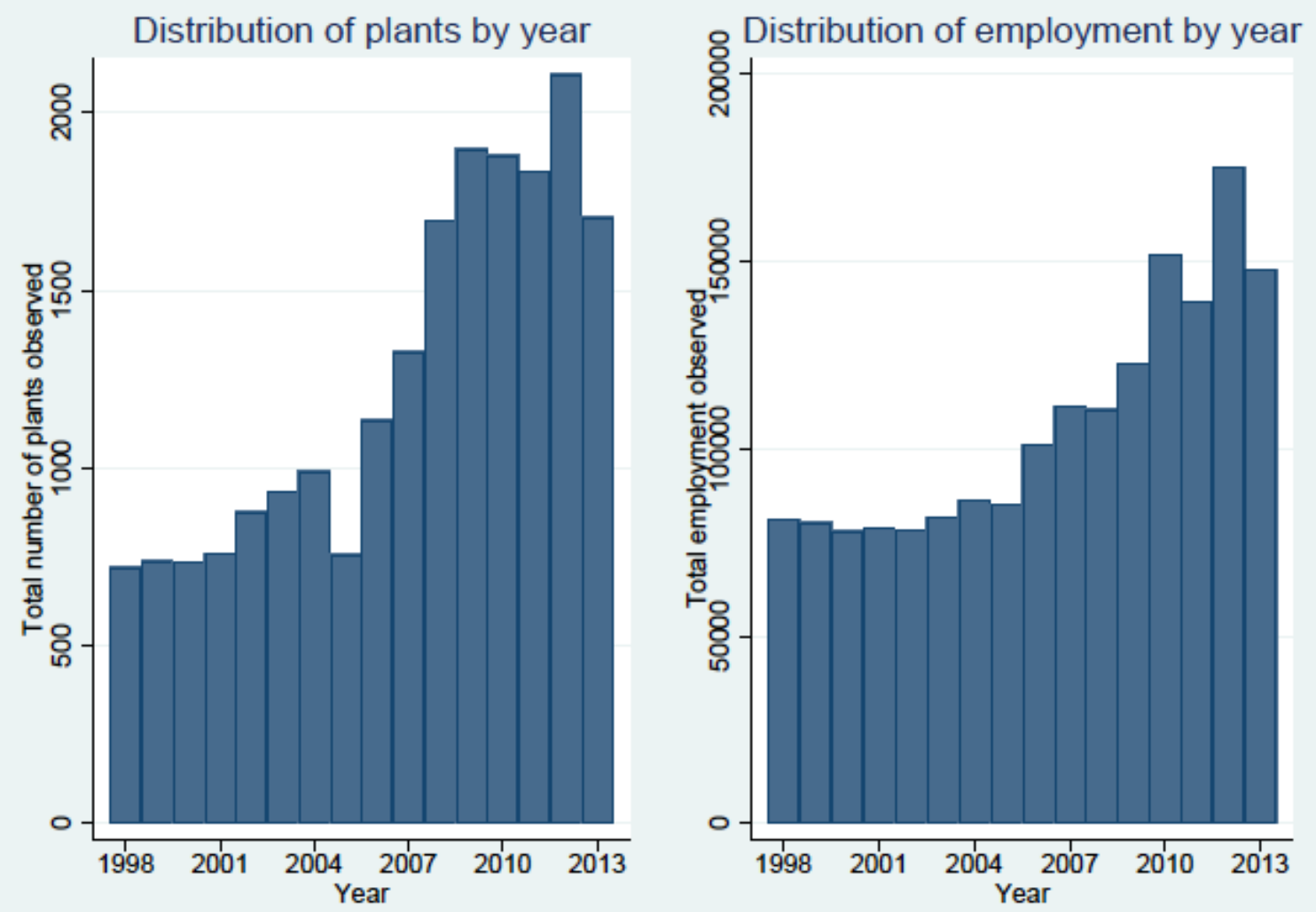

Note: The Figure shows the count of plants and the total employment by year in the matched CSA sample. 
Figure A.3: Domestic Plants' Productivity, Relative to the Year of a Foreign Plant Opening

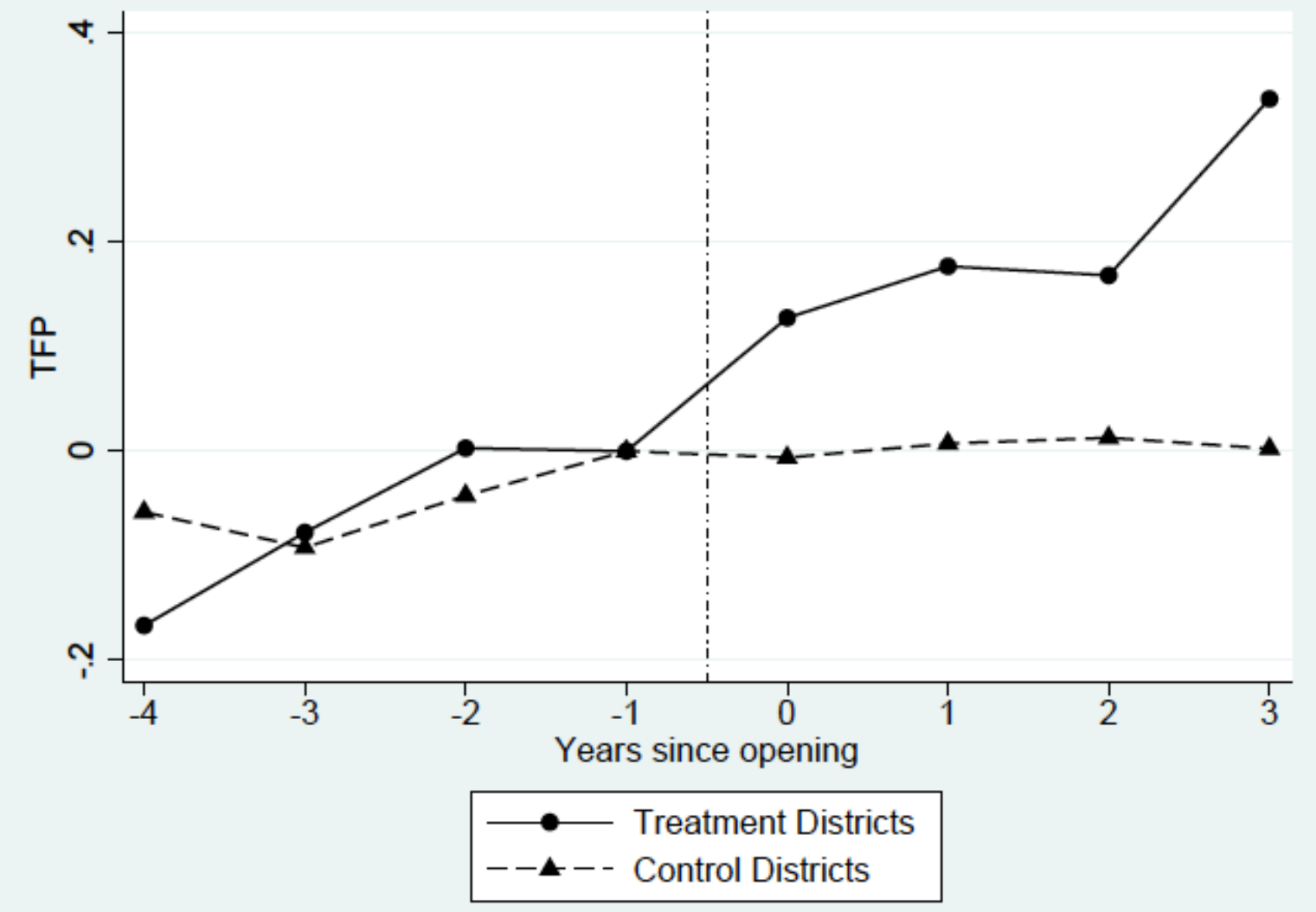

Note: The figure plots point estimates for leading and lagging indicators for the large foreign plant opening. The omitted category is one period prior to the large foreign plant opening. 
Figure A.4: Difference Between Year of Entry and Year of Permit

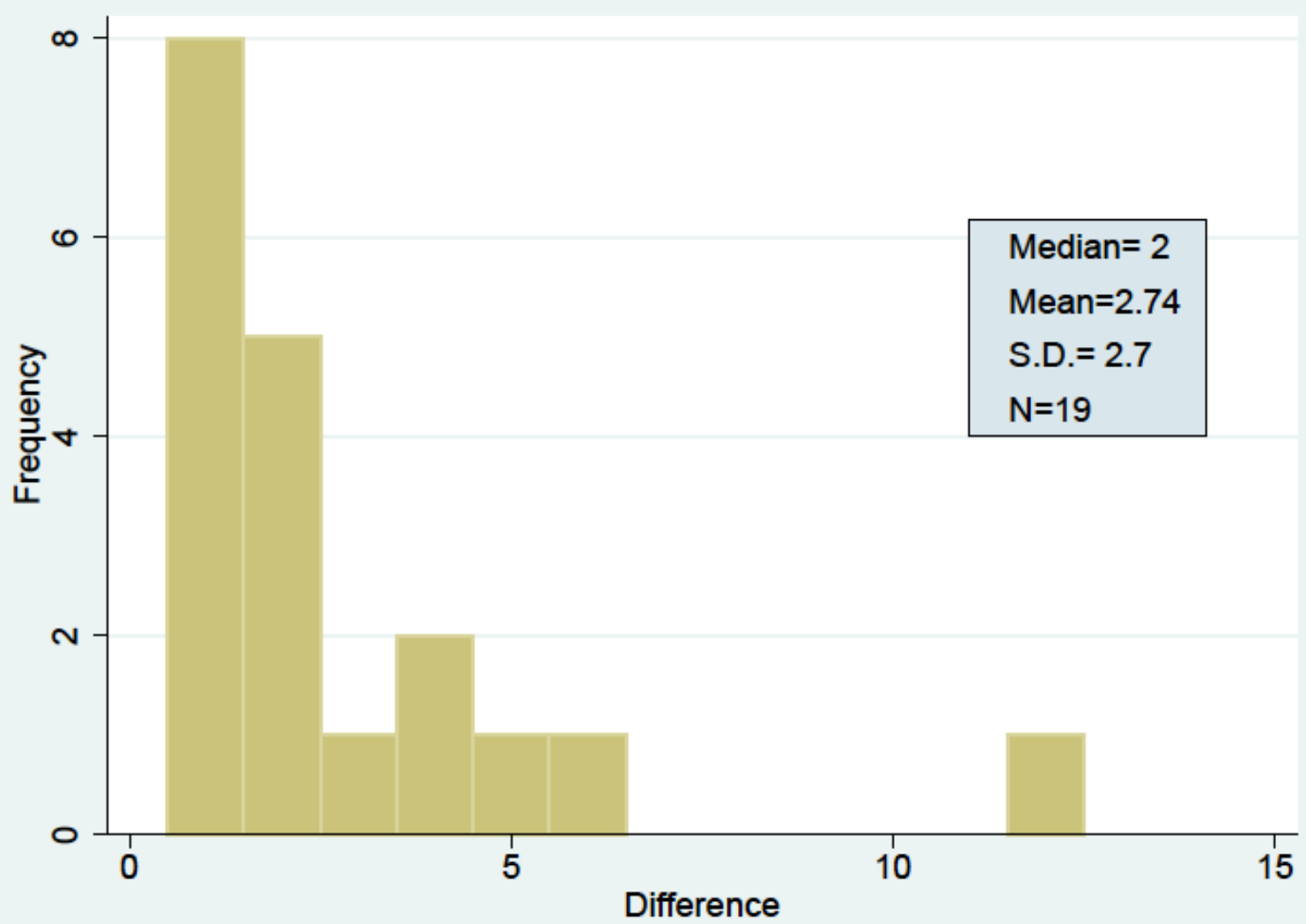

Note: Distribution of lag between licence and entry in the sample of FDI plants (a) whose labor force is at least 100 employees or constitutes at least 1 percent of total employment in local manufacturing in $\tau=0$ or $\tau=1$; and (b) whose location is not assigned by the government. 
Figure A.5: Domestic Plants' Productivity, Relative to the Year of a Foreign Plant Opening (Research Design: Government Allocation).

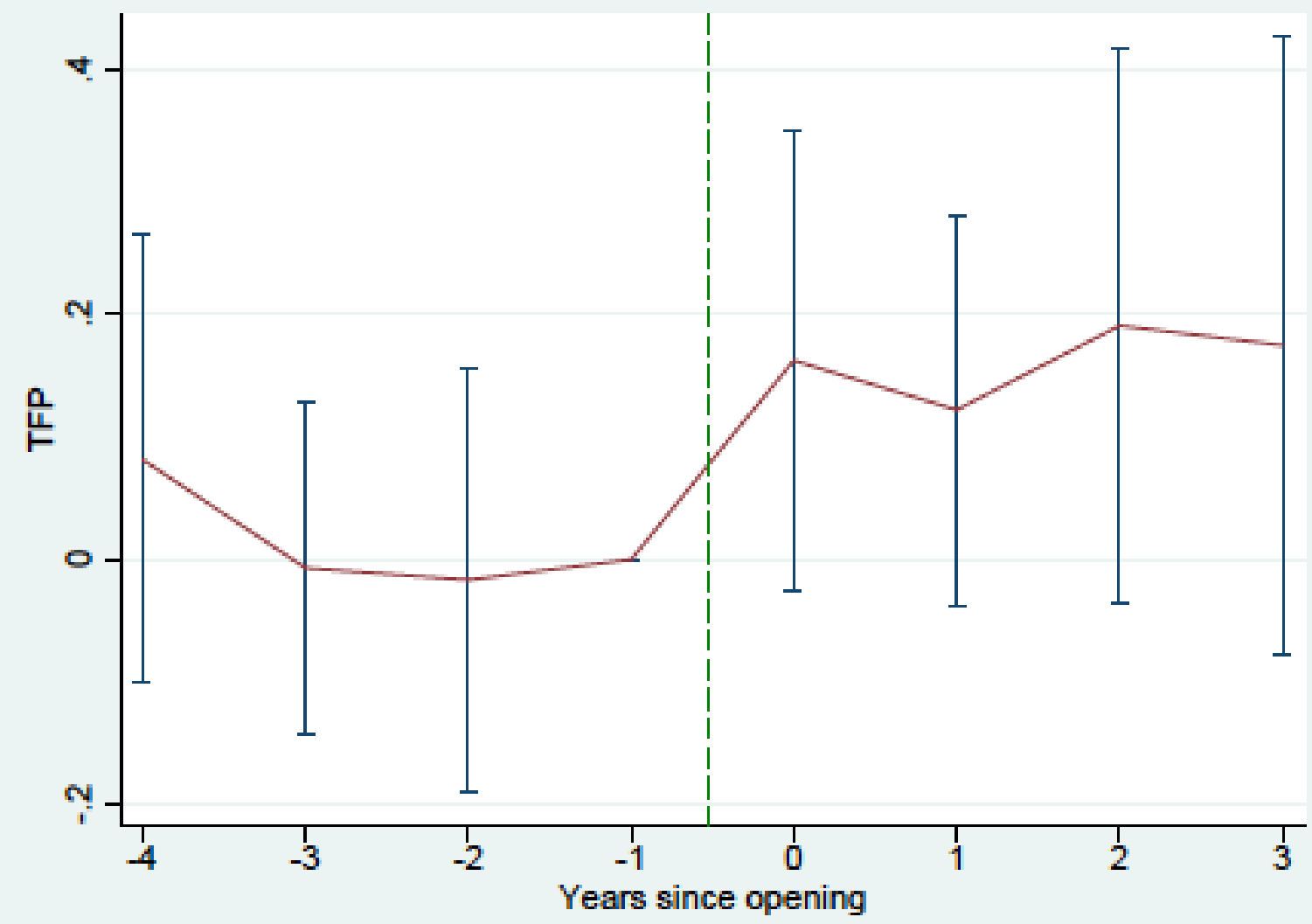

Note: The figure plots point estimates for leading and lagging indicators for the large foreign plant opening. Event time indicator "-4" set to 1 for periods up to and including 3 periods prior to the event and 0 otherwise. Event time indicator " +3 " set to 1 for all periods 3 periods after the event and 0 otherwise. The omitted category is one period prior to the large foreign plant opening. Vertical bars correspond to 95 percent confidence intervals with district-clustered standard errors. 
Figure A.6: Domestic Plants' Productivity, Relative to the Year of a Foreign Plant Opening (Research Design: Government Allocation). Treated Districts Only.

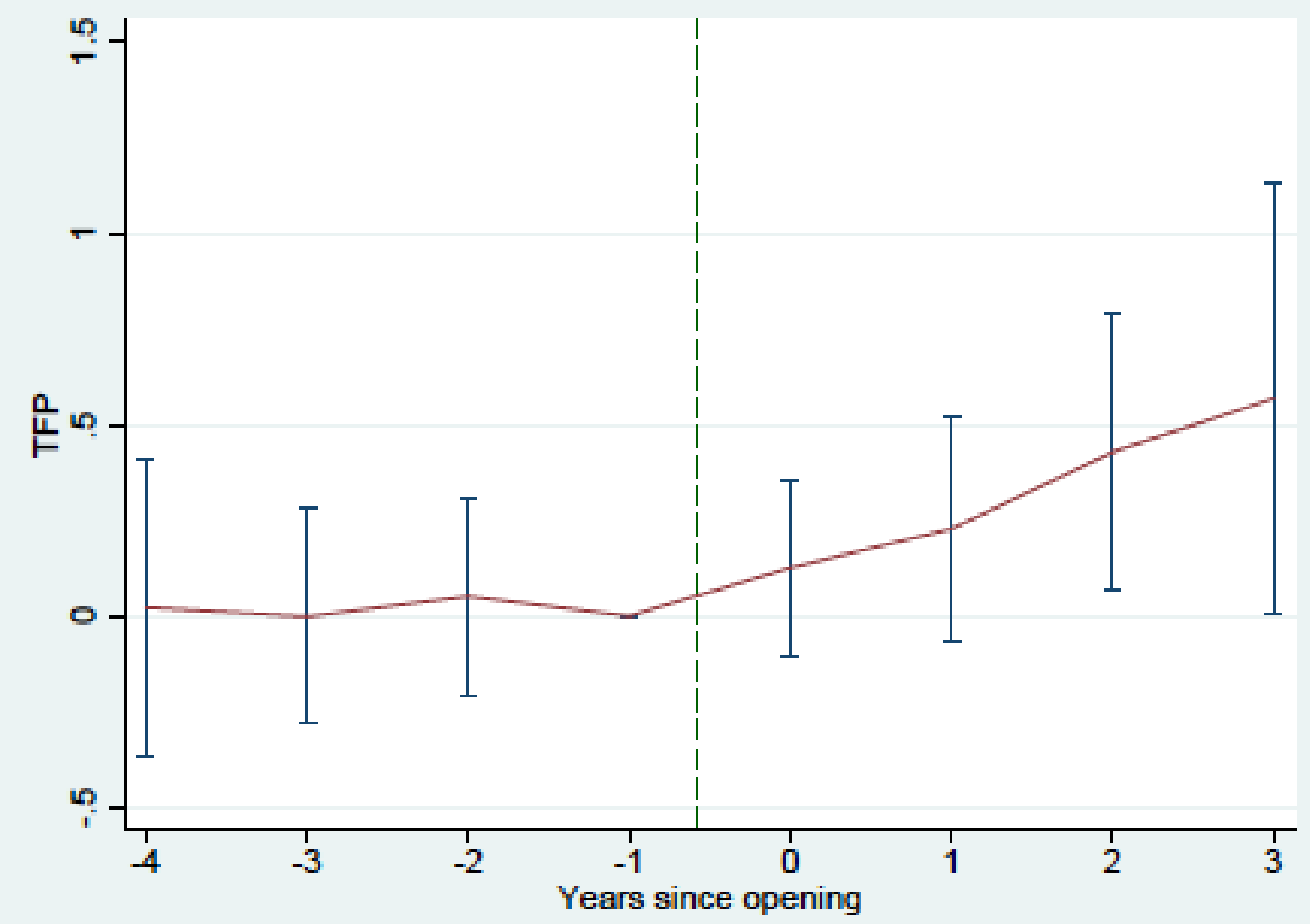

Note: The figure plots point estimates for leading and lagging indicators for the large foreign plant opening. Event time indicator "-4" set to 1 for periods up to and including 4 periods prior to the event and 0 otherwise. Event time indicator " +3 " set to 1 for all periods 3 periods after the event and 0 otherwise. The omitted category is one period prior to the large foreign plant opening. Vertical bars correspond to 95 percent confidence intervals with district-clustered standard errors. 
Table A.1: CSA Matched Sample

\begin{tabular}{lccccc}
\hline Variable & Mean & (Std. Dev.) & Min. & Max. & N \\
\hline & & & & & \\
Plant Age & 14.18 & $(14.58)$ & 1 & 91 & 19,751 \\
Employees & 88.93 & $(260.45)$ & 1 & 7,909 & 20,131 \\
Capital per Worker & 183.98 & $(1183.48)$ & 0 & 98,124 & 19,431 \\
Capital & $15,205.29$ & $(80718.31)$ & 0 & $3,973,484$ & 19,920 \\
Average Yearly Wage & 16.45 & $(59.62)$ & 0 & 5,518 & 20,106 \\
\hline
\end{tabular}

Note: Summary statistics from 6,321 unique plants, observed across all years (1996-2013). All monetary amounts are in 1000s of 2013 Birr. 'Average Yearly Wage' is the plant-level average yearly wage. 
Table A.2: Sample of FDI Opening and Districts (Research Design: Government Allocation)

Sample FDI openings

17

Never-treated districts

206

Reported year of foreign plant opening:

1999-2005

3

2006-2012

14

Foreign plant industries:

$\begin{array}{lr}\text { Non-metallic mineral products } & 8\end{array}$

Wood, furniture \& paper 4

Food \& beverages 3

Basic metals

Chemicals \& chemical products 1

Foreign plant characteristics:

Number of Employees $\quad 51.29$

$\begin{array}{lr}\text { Share of local labor market }(\%) & 18.69\end{array}$

(16.35)

Note: This Table displays descriptive information on the usable openings and districts used in the second research design. The values for 'Number of Employees' and 'Share of local labor market' are the average between $\tau=0$ and $\tau=1$. Standard deviations are shown in parentheses. 
Table A.3: Domestic plants' productivity: average of the event-study coefficients between $\tau=0$ and $\tau=2$ (Research Design: Government Allocation)

(1)

(2)

(3)

(4)

(5)

Materials-Capital

Treated Only At least 3 years

Materials-Capital Interactions

0.168

$(0.086)^{*}$

$(0.162)^{*}$

[0.080 $]^{*}$

$\begin{array}{cc}0.261 & 0.286 \\ (0.136)^{*} & (0.162)^{*} \\ {[0.050]^{*}} & {[0.080]^{*}}\end{array}$

Observations

4730

968

569

4730

4730

Districts

223

17

Note: This table reports results from fitting several versions of eq. (10). The dependent variable is $\log$ (Output). 'Average change' refers to the average of the coefficients in periods $t=0,1$, and 2 . Column 2 drops the never treated localities. This column accompanies Figure A.5. Column 3 reports estimates from the specification of Column 2, but domestic plants are required to be in the data for at least 3 years prior to the event. Column 4 adds to Column 1 a fourth-degree polynomial function of log capital and $\log$ materials (see Levinsohn and Petrin 2003). Column 5 adds interactions between log materials and log labor to the controls in Column 4 (see Ackerberg, Caves and Frazer (2015)). For Columns 2 and 3, we report in brackets the p-value obtained using the bootstrap procedure developed by Cameron, Gelbach and Miller (2008). $\log (\mathrm{L}), \log (\mathrm{K}), \log (\mathrm{M})$, plant FE and region trends are always included. 